ANALYZING AND REFORMING TUNISIA'S TAX SYSTEM James Alm

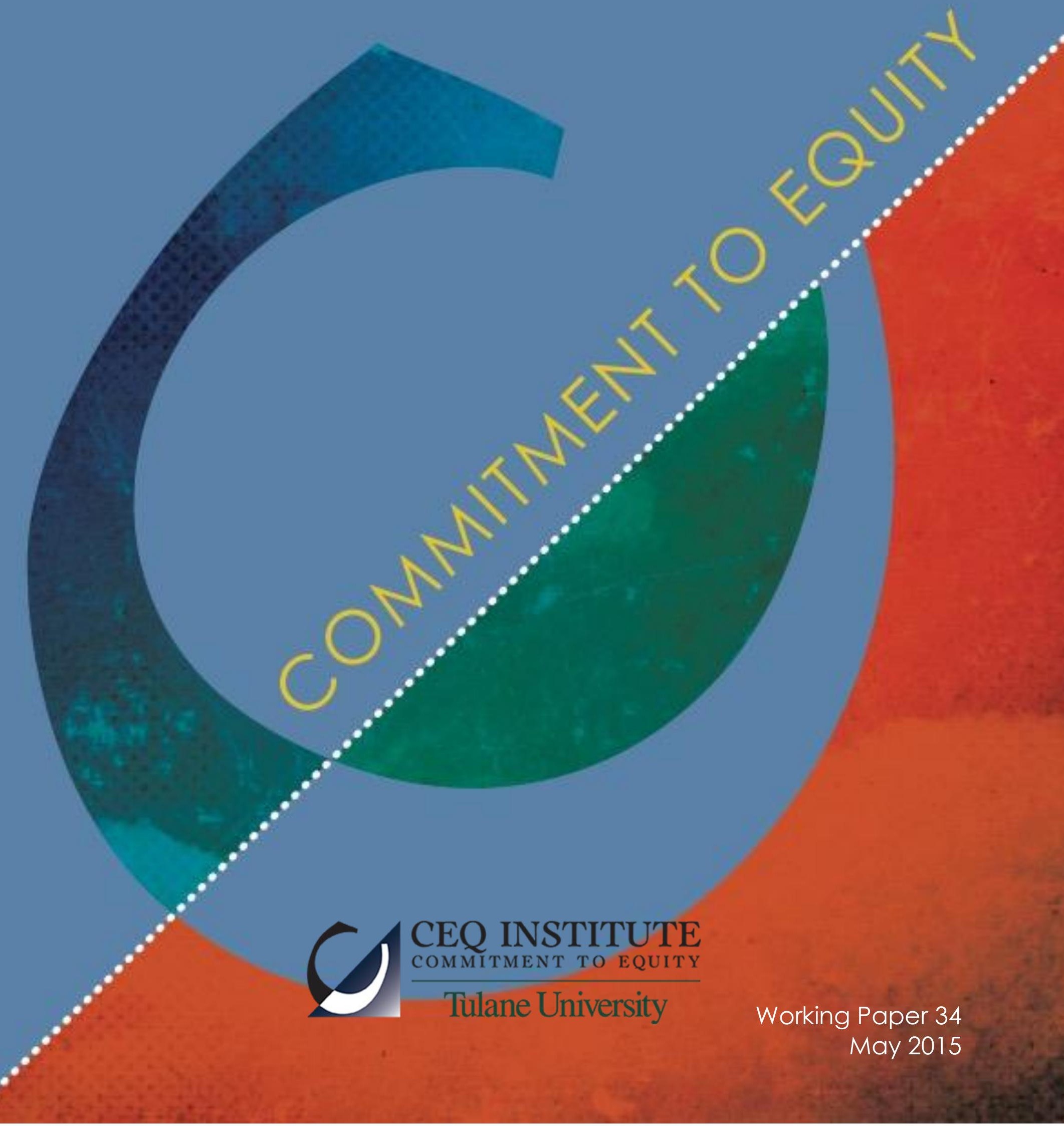




\section{The CEQ Working Paper Series}

The CEQ Institute at Tulane University works to reduce inequality and poverty through rigorous tax and benefit incidence analysis and active engagement with the policy community. The studies published in the CEQ Working Paper series are pre-publication versions of peer-reviewed or scholarly articles, book chapters, and reports produced by the Institute. The papers mainly include empirical studies based on the CEQ methodology and theoretical analysis of the impact of fiscal policy on poverty and inequality. The content of the papers published in this series is entirely the responsibility of the author or authors. Although all the results of empirical studies are reviewed according to the protocol of quality control established by the CEQ Institute, the papers are not subject to a formal arbitration process. The CEQ Working Paper series is possible thanks to the generous support of the Bill \& Melinda Gates Foundation. For more information, visit www.commitmentoequity.org.

The CEQ logo is a stylized graphical representation of a Lorenz curve for a fairly unequal distribution of income (the bottom part of the $\mathrm{C}$, below the diagonal) and a concentration curve for a very progressive transfer (the top part 61 TonMitThent of the C). 


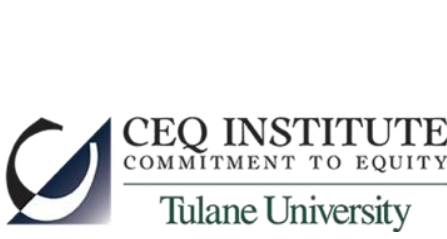

\title{
ANALYZING AND REFORMING TUNISIA'S TAX SYSTEM*
}

James $A l m^{\dagger}$

CEQ Working Paper 34

MAY 2015

\begin{abstract}
Tunisia's tax system has undergone significant structural reforms over the last several decades. Even so, its structure exhibits some major flaws, shortcomings that spill over to and affect the performance of the overall Tunisian economy. Further, the tax system continues to underperform in some fundamental ways, ways that also affect the rest of the economy. Finally, the structure of the Tunisian tax system has some notable shortcomings. This paper discusses these issues. It presents details of the main taxes, it analyzes several main features of this tax system, and it suggests various specific tax reforms that can be introduced both in the short term and in the longer term.
\end{abstract}

Keywords: Tunisia, tax reform

JEL: H20, H24, H25, H87

\footnotetext{
* This is a paper of the Commitment to Equity Institute, Tulane University. Launched in 2008, the CEQ project is an initiative of the Center for Inter-American Policy and Research (CIPR) and the Department of Economics, Tulane University, the Center for Global Development and the Inter-American Dialogue. The CEQ project is housed in the Commitment to Equity Institute at Tulane. For more details, visit www.commitmentoequity.org.

† Please address all correspondence to Department of Economics, Tulane University, 208 Tilton Hall, New Orleans, LA 70118 USA (phone +1 504862 8344; fax +1 504865 5869; e-mail jalm@,tulane.edu).
} 
Alm, WP 34, May 2015

\section{Introduction}

Tunisia's tax system has undergone significant structural reforms over the last several decades. Even so, however, its structure exhibits some major flaws, shortcomings that spill over to and affect the performance of the overall Tunisian economy. Further, the tax system continues to underperform in some fundamental ways, ways that also affect the rest of the economy. Finally, the structure of the Tunisian tax system has some notable shortcomings. This chapter discusses these issues. It presents details of the main taxes, it analyzes several main features of this tax system, and it suggests various specific tax reforms that can be introduced both in the short term and in the longer term.

As demonstrated below, relative to international competitors, Tunisia has a high marginal effective tax rate for businesses. Tunisia also has a range of fiscal and financial incentives for businesses, which have likely led to significant amounts of economic activity locating in offshore firms and which have also contributed to significant revenue losses. Finally, Tunisia has imposed high personal income and, especially, payroll tax rates. However, although the income and payroll tax rates on labor are high, the revenues from these taxes do not seem excessively high by international comparisons. This latter result suggests that there likely is much informality regarding labor tax payments, which is consistent with significant amounts of evasion and avoidance activities and which is also consistent with a widespread perception that tax rates are in fact high. Moreover, this evidence suggests that rates could be reduced, maybe even substantially, without much fiscal impact. Reducing the overall tax burden and rationalizing the payroll tax regime, while shifting to a heavier focus on indirect taxes, is important for encouraging better economic performance, including especially higher rates of formal sector job creation as the total tax burden on labor (personal income tax plus employer and employee Social Security contributions) declines.

The next section describes the current Tunisian tax system in some detail. The following sections compare Tunisian tax practice to international practices and analyze some of the main effects of these taxes. The final section presents some issues that need to be considered in any possible reform of the tax system.

\section{The Tax System in Tunisia}

The Tunisian tax system can be divided into two major categories: direct taxes (including the corporate income tax, the personal income tax, and payroll taxes) and indirect taxes (e.g., the value added tax and consumption duties). The tax system includes the following taxes:

- Customs taxes

- Value added tax

- Consumption duties

- Personal income tax

- Corporate income tax

- Registration taxes and stamp duties

- Various taxes on certain products, transportation, insurance, hotels, and the like.

Even aside from the individual income tax, the government imposes a variety of taxes on the wages of workers. Some of these taxes are more properly viewed as "contributions" because individuals are 
entitled to benefits, the size of which varies with their contributions. Some may also be seen as a way to force people to save for old age or for insurance against health problems and occupational injury. Several have all the features of a tax, but nevertheless do not go into the general revenues of the government and instead are used to finance government and non-government provision of social insurance. In total, these various payroll taxes (or "Social Security contributions") constitute a significant additional burden on labor.

Since 1988, the Tunisian tax system has undergone a series of reforms as part of broader structural reforms in different economic sectors and financial companies. These reforms have affected all types of taxes. Overall, following broad principles of "best" international practices, tax rates have been reduced, tax bases have been broadened, incentives have been streamlined, and various administrative procedures have been implemented to ensure that taxpayers have more legal protections. The main reform procedures have included institution of a VAT (from 1 July 1988), establishment of a single tax on income and profits, redesign of registration and stamp taxes, rationalization of tax and financial incentives, revision of insurance sector taxation, reform of some local taxes, and promulgation of the Code of Tax Rights and Procedures. Collections from these various taxes and contributions are shown in Table 1 (in millions of TND), Table 2 (as a percent of taxes), in Table 3 (as a percent of GDP).

These tables indicate several main findings. First, the ratio of taxes plus Social Security contributions to GDP is fairly constant over time at roughly 25 percent of GDP. As discussed later, this ratio is comparable to other middle income countries. Second, the value added tax (VAT) is the most important single tax, accounting for nearly $1 / 3$ of total taxes. Third and relatedly, indirect taxes are a more important source of revenues than direct taxes, as measured by total collections, percent of total Taxes, and percent of GDP. However, the relative importance of direct taxes (i.e., corporate income taxes, personal income taxes) has increased over time. Further, the relative importance of Social Security contributions has also increased over time. Both of these trends suggest a growing relative burden on labor.

Each of the major taxes is considered next.

Personal income tax (PIT). The personal income tax is due from any person who is a permanent resident of Tunisia. Nonresidents are also subject to the tax based on their Tunisian income.

Taxable income is based on a "comprehensive income" concept, and includes in principle income from: salaries, wages, pensions and annuities; business profits; benefits of non-commercial professions; profits from farming and fishing; salaries, wages, pensions and annuities; property income; foreign source income if the individual has not paid income taxes in the country of source. Capital gains are taxed as ordinary income for residents, with some preferences for longer held properties; for example, the tax rate is 5 percent if the property is held longer than 10 years. The unit of taxation is the individual, and joint returns are not allowed.

There are various exemptions, exclusions, and deductions. The net income of individuals is determined after deduction of 10 percent for salaries and wages, 25 percent for pensions and annuities (which increases under some conditions to 80 percent for pensions and annuities from abroad under certain conditions, and 30 percent for property tax revenues and profits for noncommercial professions determined on a contract basis. Excluded forms of income include: salaries for foreign diplomatic and consular subject to reciprocity; payments for compensation for injury, 
dividends; interest from deposits and securities in foreign currency or convertible TND; interest of home savings accounts; interest from special savings accounts opened with the National Savings Bank of Tunisia (CENT) and banks and bonds revenue within certain limits. Deductions are allowed (within certain limits) for: premiums on life insurance contracts; deductions for marital status and dependents (e.g., married taxpayer, dependent children, dependent parents); a 500 TND additional deduction for employees earning the minimum wage; and income reinvested in the capital subscription of companies under the conditions laid down in legislation governing the tax benefits.

The tax rates imposed on the resulting based are progressive, starting at 15 percent for net income between 1500 and 5000 TND and rising to 35 percent on net income above 50,000 TND:

\begin{tabular}{|l|l|}
\hline Taxable income (TND) & Tax rate (percent) \\
\hline $0-1500$ & 0 \\
\hline $1500-5000$ & 15 \\
\hline $5000-10,000$ & 20 \\
\hline $10,000-20,000$ & 25 \\
\hline $20,000-50,000$ & 30 \\
\hline Over 50,000 & 35 \\
\hline
\end{tabular}

The personal income tax is paid mainly via source withholding tax on wages, fees, commissions, rents, movable capital, royalties, contracts, and amounts equal to or greater than 1000 TND paid by the state and public authorities or greater than 5000 TND paid by corporations and individuals under the real Regime. It may also be paid via three installments each equal to 30 percent of the tax of the previous year payable during the $6^{\text {th }}, 9^{\text {th }}$, and $12^{\text {th }}$ months. The withholding and advance installments are deductible from the final tax.

Corporate income tax (CIT). Like most corporate income taxes, the tax is imposed on the net income of companies, determined from accounting records in accordance with the law after deducting all expenses and professional charges, including: depreciation (on a straight line, declining balance, or accelerated basis); provisions for "bad" debts (under some conditions); inventory adjustments; donations and grants (up to a maximum of 2 percent of sales); and reinvested earnings (under some conditions). As with the personal income tax, capital gains are taxed as ordinary income. The tax is due from capital companies established in Tunisia, from cooperatives, from public non-administrative companies having a profit, and from foreign businesses not established in Tunisia because of their Tunisian source income. Losses may be carried forward for four years, and deferred depreciation may be carried forward indefinitely. The distribution of dividends is exempt from any tax.

The general tax rate in the corporate income tax is 30 percent. There is also a reduced rate of 10 percent that is applicable to small businesses, agriculture, handicrafts, and fishing, and there is a different (and higher) tax rate of 35 percent on firms in the financial, telecommunications, insurance, oil production, refining, transport, and distribution sectors.

The Ministry of Finance indicates that there were in total 103,772 companies in Tunisia at the end of 2012. Of these, 21,017 were joint-stock companies operating as offshore companies, 80,890 were joint-stock non-offshore companies, and 1859 were partnerships (27 offshore and 1832 non- 
offshore companies). The dominant sectors in terms of numbers of firms were services $(27,476)$, industrial activities $(22,638)$, non-commercial activities $(19,228)$, wholesale trade activities $(18,348)$, and retail trade activities $(13,318)$.

Value added tax (VAT). The value added tax (VAT) is imposed on the difference between revenues and purchased inputs (e.g., the "value added") in goods and services, merchandise imports, industrial and artisanal production, services, wholesale trade (other than food, drugs, and pharmaceuticals), retail trade when the overall annual turnover exceeds 100.000 TND (excluding food, medicines, pharmaceutical products, and products subject to the approval of administrative prices). Some professions are exempt, as are some products (e.g., books, newspapers, periodicals, milk, bread, couscous, vegetable oil) and some services (e.g., international air transport, maritime transport, bank interest receivable).

The tax base for imports is the customs value of the good, including all costs, duties and taxes other than VAT for taxable, as established by Decree No. 2003-477 of 3 March 2003. The base for other (internal) products is in the price of goods, works, or services, including all fees, charges, and taxes (excluding the VAT itself).

Tax rates vary by type of good: 6 percent for fertilizer, handicrafts, medical activities, canned food, and compound feed for cattle; 12 percent for computers, computer services, hospitality, food, equipment not produced locally, and 4 horsepower cars; and 18 percent as the general rate applicable to products and services not subject to another rate. Goods and services subject to these specific rates (e.g., 6 percent, 12 percent, 18 percent) and exempt goods and services are determined in specific tables. Exports are zero-rated.

The VAT is collected using the credit invoice method. The VAT paid on inputs is deductible (or credited) from the VAT collected on sales of the month. The credit is carried forward to the next month, or refundable under some conditions.

Consumption duties. Consumption duties are applied to: wine, beer, alcohol and alcoholic beverages; tobacco; fuels; and personal vehicles. The taxes are imposed either as ad valorem rates (starting at 10 percent) or as specific taxes (e.g., on wine, beer, alcohol and alcoholic beverages, fuels).

Registration fees. Various registration fees are imposed on such activities and transactions as the sale of property, the sale of business assets, gifts and inheritances, acts of companies, and legal judgments. These taxes are imposed either as ad valorem rates or as specific excises. For example, the sale of property is taxed at 5 percent of the value for the sale of property, sales of business assets are taxes at 2.5 percent of the value for sales of business assets, and gifts and inheritances are taxed at 2.5 percent for transfers between spouses, 5 percent between siblings, and 25 percent or 35 percent for other degrees of relationship. Specific taxes are 15 TND per action for the transfer of assets and securities under certain conditions, and 100 TND per action for company activities like incorporation.

Other indirect taxes. There are various miscellaneous indirect taxes such as: the professional training tax at the rate of 1 percent of gross payroll for manufacturing industries and the rate of 2 percent in other cases; the contribution to the fund to promote social housing at a rate of 1 percent of gross 
payroll; and a tax on insurance contracts at 5 percent of written premiums for insurance contracts for maritime and air transport and at 10 percent for other contracts.

Social Security contributions. There are several payroll taxes that finance various types of social insurance for employees, including pensions and protection against risks like unemployment, disability, sickness and maternity. The applicable social security regimes differ according to the professional category. In the non-agricultural sector, there is a general regime, and a supplemental regime for self-employed; in agriculture, employees and the other operators are covered. The contribution rates vary by regimes, and the resulting benefits also vary by regime. For example, nonagricultural self-employed workers do not receive family benefits, and agricultural employees, selfemployed workers in the non-agricultural sector, farmers and self-employed in agriculture, and public officials benefit from specific provisions.

Employers with employees are required to join the National Social Security Fund. Self-employed workers may join voluntarily, in order to ensure against the risks of labor accidents and occupational diseases. Public officials have a special regime. The Security Fund (CNSS) administers pensions, disability, survivor, death, unemployment, and family benefits through its regional offices in the capitals of governorates. Sickness, maternity, work accidents, and occupational diseases are managed by the National Fund of Health Insurance (CNAM).

The contribution rates are generally imposed on full wages of the worker (although the supplementary pension contributions are paid on the portion of salary that exceeds six times the minimum wage). Each program has a different employee and employer contribution rate. For example, the employer contribution to the old age, disability, and survivor scheme is 7.76 percent, and the employee contribution is 4.73 percent. The contribution rates for sickness and maternity are 5.08 percent and 3.16 percent. The mandatory contribution to the accidents and occupational diseases regime is borne only by the employer, and it varies between 0.4 percent and 4 percent by sector of activity; this contribution may be increased or reduced, depending on whether the employer breaches safety rules or makes extensive prevention efforts. Contributions are made to the CNSS on a quarterly basis. These rates are:

\begin{tabular}{|l|l|l|l|}
\hline Type & $\begin{array}{l}\text { Employer } \\
\text { Contribution }\end{array}$ & $\begin{array}{l}\text { Employee } \\
\text { Contribution }\end{array}$ & Total \\
\hline Old age, disability, and survivor & $7.76 \%$ & $4.73 \%$ & $12.50 \%$ \\
\hline Sickness and maternity & $5.08 \%$ & $3.16 \%$ & $8.24 \%$ \\
\hline Family benefits & $2.21 \%$ & $0.88 \%$ & $3.10 \%$ \\
\hline Accidents / Occupational diseases & $0.4-4 \%$ & - & $0.4-4 \%$ \\
\hline $\begin{array}{l}\text { Welfare workers - Special Fund of } \\
\text { State }\end{array}$ & $1.51 \%$ & $0.38 \%$ & $1.90 \%$ \\
\hline Total & $16.97-20.57 \%$ & $9.18 \%$ & $26.15-29.75 \%$ \\
\hline Supplementary pension & $6 \%$ & $3 \%$ & $9 \%$ \\
\hline
\end{tabular}

Note: The Supplementary pension is only for those companies that elect to join this regime.

In total, the combined employer and employee tax rate ranges from 26.15 to 29.75 percent. Participation in the supplementary pension adds another 9 percent to these contribution rates. 
Fiscal, financial, and other incentives. Passed as legislation in January 1994, the Investment Incentives Code governs both national and foreign investment. Three classes of incentives exist under the Investment Incentives Code: financial incentives that involve the direct transfer of funds (e.g., grants, loans) from the treasury; fiscal incentives like tax exemptions or credits whereby government revenue that is otherwise due is foregone; and the giving of public lands for nominal sums of money. These incentives are available to: "offshore" companies operating in export processing zones (EPZ); companies engaged in industrial, agricultural, tourism, and public works projects; companies that provide services; companies engaged in health, education, and environmental initiatives; and investments in underdeveloped regions. Small and medium sized enterprises are also accorded special status under the law. Commercial activities, financial services, mining operations, and energy activities are not eligible for any such incentives.

Tunisia's "offshore" investment framework operates as a traditional enterprise-specific EPZ regime. Offshore EPZ companies that export 70 percent of their finished goods or services are entitled to corporate income tax, VAT, customs duty, consumption taxes, turnover taxes, and foreign exchange control exemptions. Nevertheless, the various employee-related taxes remain applicable, including the personal income tax and Social Security contributions, both for employee and employer contributions. Foreign nationals working for an offshore EPZ company are entitled to a preferential, fixed personal income-tax rate of 20 percent. Offshore EPZ companies enjoy the legal right to sell 30 percent of their finished goods or services in the local home market; however, such sales are subject to all applicable taxes, duties, and foreign exchange controls, including the 30 percent corporate income tax, the governing VAT, applicable customs duties, the 10 percent consumption tax, and the governing turnover tax.

Effective 1 January 2013, offshore EPZ companies will be subject to a 10 percent corporate income tax for their export sales. This legislative modification was required for Tunisia to comply with its international obligations arising under the WTO Subsidies Agreement. Nevertheless, the 20 percent differential between this forthcoming 10 percent income tax rate and the generally applicable 30 percent income tax rate constitutes an export subsidy that is per se prohibited by the WTO Subsidies Code. No available evidence appears to exist on the WTO website that demonstrates that the WTO Subsidies Committee has ever granted Tunisia an extension to maintain its offshore export subsidies.

There are also several "common" incentives, including tax relief on reinvested profits and income up to 35 percent of the income or profits subject to tax, customs duties exemptions for capital goods that have no locally made counterparts, and VAT exemptions on some capital goods imports (1999 Finance Act provisions).

More specific incentives are of several types. First, there are advantages to fully exporting companies. These incentives include, such as: full tax exemption on export-derived profits for the first 10 years and taxation at a low rate after for companies established before 2012; taxation at the rate of 10 percent for the first 10 years for the companies established in 2012; full exemption on reinvested profits and income; duty free profits for capital goods including merchandise transport vehicles, raw materials, semi-finished products, and services needed by the business; and the possibility of selling on the local market (i.e., 30 percent of turnover for industrial goods and agricultural products, along with payment of applicable duty and levies, increased to 50 percent for the year 2011). 


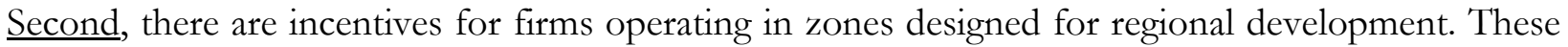
incentives are similar to those for exporting companies, and include: full tax exemption on reinvested profits and income; deduction from the tax base for the personal or the corporate income tax of income or profits on investments in industry, tourism, handicrafts, or certain service activities (e.g., tax holidays); and assumption by the state of the employer's contribution to the Social Security system.

Third, there are incentives for agricultural development, including: full tax exemption on reinvested profits and income; full tax exemption for the 10 first years of operation; VAT suspension on imported capital goods that have no locally-made counterparts; state provision of infrastructure expenses to develop areas meant for fish farming and for cultivations using geothermal water; 7 percent bonus on investment value; 8 percent additional bonus on investment value granted for agricultural investments achieved in hard-climate regions (e.g., Gabes, Gafsa, Medenine, Kebili, Tataouine, Tozeur), which can go as high as 25 percent for areas around Gafsa that are in the process of converting from mining to other activities; and 25 percent additional bonus on investment value for fishing projects in the north coastline ports from Bizerte to Tabarka.

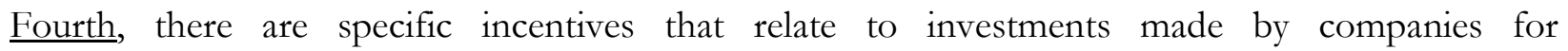
environmental protection and waste processing (e.g., 50 percent tax reduction on reinvested income or profits, taxation of income and profits at a reduced 10 percent rate, 20 percent premium on the value of investments, and VAT suspension on specific capital goods).

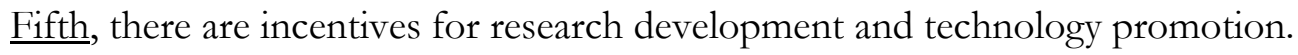

Sixth, there are specific incentives to support investment by education, training, cultural production, health and transport industries. These incentives include the deduction of reinvested profits up to 50 percent of net profits subject to corporate tax, a reduced tax rate of 10 percent on income and profits, and VAT suspension for imported capital goods having no similar locally-made counterparts.

Le Regime Forfaitaire. Like nearly all countries, Tunisia attempts to simplify the compliance burden on some specific types of taxpayers by the use of a simplified tax system, called Le Regime Forfaitaire. The use of this regime for some taxpayers is broadly consistent with the use of presumptive methods of income taxation for these taxpayers, in which the "desired" base for taxation is not itself measured but is instead inferred from some simple indicators that are more easily measured than the base itself. Presumptive methods are used for a variety of reasons: to reduce the compliance costs on taxpayers by making it easier for these taxpayers to compute their tax liabilities, to simplify tax administration by removing some taxpayers (usually those with small tax liabilities) from the tax rolls and by providing more obvious and more direct measures of tax liabilities, to improve tax equity by providing more objective indicators of tax assessment, to reduce corruption by eliminating official discretion in assessing tax liabilities, to encourage taxpayers to keep better accounts in order to provide documentation that may reduce their presumptive tax liabilities, and to improve incentive effects when, say, income above the presumptive level is not subject to taxation.

This simplified tax system in Tunisia has been in force since 1 January 2011. It is intended for individual-owned firms that meet certain criteria. For example, the individual cannot import, cannot manufacture alcohol-based products, and cannot own more than one vehicle whose load cannot exceed 3.5 tons. Most importantly, the annual turnover of the firm cannot exceed 100,000 TND (for 
Alm, WP 34, May 2015

firms that resell, process, and consume onsite) or 50,000 TND (for service activities). The tax rate is Tunisia is 2 percent for firms that resell/process/consume, and 2.5 percent for all other firms. The forfaitaire liability cannot be less than 50 TND for firms outside communal areas and less than 100 TND for other firms. Importantly, eligible firms do not have to pay other taxes. Recent information (2012) from the Ministry of Finance indicates that of 633,177 registered taxpayers, 408,369 are in Le Regime Forfaitaire.

Local government taxes. Local governments impose a variety of taxes and fees, including: a tax on commercial, industrial, or professional companies; a hotel tax; a property tax; a tax on undeveloped lands; market fees; and fees for electricity, street lighting, and maintenance. These taxes and fees in total generate little revenues.

\section{Some International Comparisons}

Tunisia raises roughly one-quarter of GDP in taxes in 2010. A natural question to ask is whether Tunisia has an "adequate" level of revenue mobilization. This is no easy question to answer. There is also the question of whether the competitiveness of the Tunisian economy is weakened by overreliance on certain forms of taxation (e.g., income taxes) relative to other comparable countries; that is, the structure of taxation in Tunisia is a relevant consideration. The tax rates of the individual taxes are also essential factors. Each of these areas is discussed.

Level of Taxes. When the level of taxation (including Social Security contributions) in Tunisia (as a percent of GDP in 2010) is compared to a subset of relevant Middle East and North Africa (MENA) countries (e.g., Algeria, Bahrain, Djibouti, Egypt, Iran, Iraq, Israel, Jordan, Kuwait, Lebanon, Libya, Malta, Morocco, Oman, Qatar, Saudi Arabia, Syria, United Arab Emirates, West Bank and Gaza, Yemen), taxes relative to GDP are generally higher for Tunisia than for the median of other MENA countries. More generally, Table 4 shows the average level of taxes as a percent of GDP by country grouping for the last four decades. Tunisia's level of taxes is lower than industrialized countries but higher than developing countries, roughly half-way between the levels of taxes in these two groups.

A more traditional "tax effort" analysis gives similar conclusions. Using IMF data, it is possible to compare the tax ratio (Taxes plus Social Security contributions as a share of GDP) for 117 countries. These data show the ratio for Tunisia to be 23.5 percent of GDP in 2005, by comparison with an average for this sample of countries of 23.6 percent of GDP. This simple comparison suggests that Tunisia has an average level of taxation, although averages are misleading because countries may be different from one another in terms of their capacity to tax.

The use of ordinary least squares (OLS) regression analysis provides a more controlled examination of tax effort, in which a set of explanatory variables that reflect country differences in taxable capacity is used to predict taxes as a percent of GDP. These independent variables and the hypotheses about the ways in which they should effect tax revenue mobilization are:

- The level of per capita GDP should be positively related to the tax ratio because higher GDP suggests a greater capacity to tax.

- The degree to which the economy is open to trade is a determinant of the tax ratio. The greater a country's propensity to trade with other countries, the easier it is to raise revenues because the (administrative) tax handles are in place; the government may also 
Alm, WP 34, May 2015

play a larger risk-reducing role in more open economies that are exposed to greater external risks. "Openness" is measured as the sum of imports and exports divided by GDP.

- The size of the agricultural sector relative to GDP should dampen taxable capacity and be negatively related to the level of the tax ratio. Countries with a larger agricultural share have fewer good (administrative) tax handles, and the agricultural sector itself can be politically hard to tax.

- Countries with smaller populations should raise a greater share of GDP in revenues than countries with larger populations because there are fixed costs of government that are independent of country size.

- The rate of population growth is also related to the level of revenue mobilization. Faster growing places tend to lag behind in the amount of revenue they raise per dollar of GDP, in part because of lags in moving the population into the tax base.

OLS regressions can be estimated with various combinations of these explanatory variables, with all variables measured in logarithms. See Box 1. 


\section{Box 1. Regression Results for the Determinants of Tax Revenue to GDP Ratio} Some simple OLS regressions are reported in Box Table I below. The dependent variable is the ratio of tax revenue to GDP; various explanatory variables are used in different specifications. The sample consists of 119 developed and developing countries for the period 2000 to 2009 .

The explanatory variables are in general statistically significant and with the expected signs. The Tax/GDP ratio is significantly higher in countries where per capita GDP and openness are higher, and where the agricultural share of GDP and the population growth rate are lower. The regressions explain between 47 and 67 percent of the variation. The ratio of "predicted" Tax/GDP to "actual" Tax/GDP is used to generate the estimated "tax effort" of Tunisia.

\section{Box Table I. Regression Results}

\begin{tabular}{|l|l|l|l|l|}
\hline & \multicolumn{4}{l}{ Specification } \\
\hline Variables & $\mathbf{( 1 )}$ & $\mathbf{( 2 )}$ & $\mathbf{( 3 )}$ & $\mathbf{( 4 )}$ \\
\hline & -0.65 & 2.97 & 1.21 & 3.23 \\
Constant & $(1.07)$ & $(8.81)$ & $(3.75)$ & $(9.75)$ \\
\hline & 0.23 & & 0.21 & \\
Per Capita GDP & $(12.11)$ & & $(6.19)$ & \\
\hline & 0.31 & 0.27 & 0.22 & 0.32 \\
Openness & $(3.99)$ & $(3.26)$ & $(4.17)$ & $(3.12)$ \\
\hline & 0.06 & & & \\
Population Size & $(1.61)$ & & & \\
\hline & & -0.37 & & -0.26 \\
Agricultural Share of GDP & & $(7.81)$ & & $(6.43)$ \\
\hline & & & -0.19 & -0.24 \\
Population Growth Rate & & & $(4.27)$ & $(8.41)$ \\
\hline Adjusted R & & 0.47 & 0.67 & 0.65 \\
\hline Observations & 0.59 & 0.47 & 119 \\
\hline
\end{tabular}

Notes: Data are averages for the period 2000-2009. All variables are expressed in logarithms, except the population growth rate. t-statistics are shown in parentheses.

Source: Calculations by author.

These results can be used to estimate an "expected" level of the tax ratio for Tunisia. For example, across the various specifications Tunisia "should" raise on average 25 percent of GDP in taxes. The actual ratio of taxes to GDP in the 2000s was 24 percent. The ratio of the actual to the estimated is the "tax effort" coefficient. Thus Tunisia's tax effort coefficient is 0.96 , which can be interpreted as showing that Tunisia ranks comparable to but slightly (or 4 percent) below the international average tax effort, although this difference is not highly significant.

Based on this international comparison, Tunisia appears to be an average-tax country, neither a hightax nor a low-tax country. Some could point to this result as one of the competitive features of the Tunisian economy, and argue that taxes should be held at their present level. Others may see this as evidence that there is at least some room for additional taxes. 
There are important reservations to this conclusion. These results show that overall collections in Tunisia are roughly at the international average. It may well be the case that liabilities are high, and that Tunisians who comply with the tax laws face tax burdens that are high by international standards; however, it is not possible to make such a comparison among the countries in the sample because data are not available. Estimates of the Tunisian "shadow economy" are presented later.

In this regard, an important attribute of a tax system is an ability to generate automatic growth in fiscal revenues over time. A common measure of this dynamic property is the ratio of the proportional change in tax revenues to the proportional change in GDP, known as "buoyancy".

One way to measure buoyancy is with regression analysis. Using data from over the last decade to estimate the response of the natural logarithm of the revenue to the natural logarithm of GDP series, the resulting coefficient for GDP provides an estimate of the average buoyancy of the revenue series over the period. Over this period, tax revenue buoyancy has been roughly unity, or 1.02 for total tax revenues. Also, there are significant differences in performance among different sources of tax revenues. Personal and corporate income taxes, the VAT, and Social Security contributions have estimated buoyancies well in excess of 1 , excises and international trade taxes had values much below 1 . However, these estimates do not have significant precision.

Tax Structure. A different issue is whether Tunisia's tax structure (as opposed to the level of taxes) is similar to that of other countries. Table 5 presents International Monetary Fund Government Finance Statistics data for three tax groupings: income taxes, indirect taxes, and taxes on international trade. Table 5 demonstrates that the burden of income taxation is considerably higher in Tunisia than in other developing countries, and that the burden of indirect taxes sales taxes (including trade taxes) is lower in Tunisia than in other developing countries. These tax structure differences suggest that income taxes, particularly personal income taxes, are used more heavily in Tunisia than in many other comparable countries, supporting the observation made by many that Tunisia taxes labor very heavily.

Table 6 presents similar information, now broken down by specific countries and using International Monetary Fund Government Finance Statistics data for 2010, with taxes divided into four groups: income and payroll taxes, property taxes, indirect taxes, and taxes on international trade. The relative reliance on each of these groups is shown in Table 6, in a comparison of Tunisia with all countries for which data are available. Again, Tunisia has relatively heavier reliance on income and payroll taxes, and relatively less reliance on trade taxes, than the average country in this sample.

These comparisons do not control for country characteristics that might affect collections. By comparing actual personal income tax revenues (plus Social Security contributions) to estimated revenues, it is again possible to calculate indexes of tax effort by country, now by specific tax.

As in the previous analysis, the first step in calculating income tax effort is to identify variables that measure the capacity of a country to raise income tax revenue. Per capita GDP is an overall measure of capacity, and countries with higher per capita GDP are expected to raise more income tax revenue. Population size is used as an independent variable to adjust for the size of a country, with the expectation that large countries are more prone to tax personal income. The openness of a country (measured as imports plus exports divided by GDP) could be expected to identify countries with more sophisticated administrations and therefore an ability to support an individual income tax. An OLS regression of the individual income tax as a percent of GDP on a sample of 35 countries 
Alm, WP 34, May 2015

(where all variables are entered in log form and where averages of the income tax to GDP ratio for countries are used for the period 2000-2010) gives estimated coefficients as hypothesized, with all three independent variables statistically significant.

These regression results are then used to estimate an expected or predicted level of personal income taxes plus Social Security contributions for Tunisia. A country of Tunisia's income, population, and openness would on average raise 6.8 percent of its GDP in personal income taxes and Social Security contributions. In fact, Tunisia raises on average 9.1 percent, or well above the predicted amount. Tunisia's tax effort index for these taxes (or the actual percent of personal income tax revenues plus Social Security contributions divided by the estimated percent) is 1.34, among the largest in our sample. These international comparisons suggest that there is not much room for increasing the effective tax rate for the income tax and indeed that there are arguments for reducing the burden of income taxation.

Similar comparisons can be made for the other major taxes. These comparisons indicate that Tunisia is a relatively heavy user of the corporate income tax and relatively light user of indirect taxes (assuming these including trade taxes).

Tax Rates. Tunisia's tax rates are generally above international levels.

For the personal income tax, the dominant world-wide trend in the last 25 years is a significant decline in top marginal tax rates and overall marginal tax rates (Peter, Butrick, and Duncan, 2010). In a sample of 189 countries at all levels of income and in regions of the world, the GDP-weighted average top statutory PIT rate fell from a high of 62 percent in 1981 to 56 percent in 1986. During the ensuing eight year period (1986-1993), the PIT top rate fell by another 16 percentage points. It then increased by a modest 2 percentage points (1993-1996) before resuming its downward trend in 1996. Since then, the decline has continued, with average

top statutory rates falling an additional 6.5 percentage points over the next 10 years. Overall, there has been a drop of 41 percent in the weighted top PIT rate, from a high of 62 percent in 1981 to a low of 36 percent in 2005. In addition, only 17 percent of unweighted top PIT rates were in excess of 40 percent in 2001-2005 compared to over 71 percent during the early 1980s. The proportion of countries with top PIT rates in excess of 60 percent declined from one-fourth in 1981 to less than 1 percent in 2005. Countries with lower top PIT rates (or 1 to 40 percent) became more widespread over time. The percentage of countries falling into this category increased from approximately 15 percent to over 73 percent between 1981 and 2005.

Overall in 2001-2005, 9.7 percent of the 189 countries had a top marginal tax rate of 0 percent, 15.8 percent had a top rate between 1 and 20 percent, 23.3 percent had a top rate between 21 and 30 percent, 34.0 percent had a top rate between 31 and 40 percent, 16.3 percent had a top rate between 41 and 60 percent, and 0.9 percent of the countries had a top rate above 61 percent. By this comparison, Tunisia's top personal income tax rate of 35 percent places it above (if not significantly above) the median of these 189 countries.

For the corporate income tax and the VAT, Tunisia's corporate income tax is 30 percent, while its standard VAT rate is 18 percent. Table 7 indicates that these rates are higher than many (if not all) of the selected countries. In this regard, the Ministry of Finance calculates that the weighted average customs-import-duty rate ranges between 10 percent and 15 percent for all taxed items. At least 123 countries world-wide now have some form of VAT, and no tax has ever spread so quickly and so 
Alm, WP 34, May 2015

widely. Other than the U.S., every country in the OECD now has a VAT, as do most countries in the Middle East and North Africa. The average standard rate in the OECD countries is now almost 18 percent, compared to 14 percent in the western hemisphere countries. In most countries, VAT rates have gone up over time.

For Social Security contributions, Table 8 presents payroll tax rates for OECD countries and for Tunisia. Relative to these higher income countries, Tunisia's payroll tax rates are higher than 12 of these 21 countries. Relative to the generally lower income countries in Table 9, Tunisia's payroll tax rates are in general much higher.

\section{Some General Equilibrium Effects of the Tunisian Tax System}

In this section a simple general equilibrium model is used to quantify many of the effects of this system of taxes. Although all taxes contribute to these general equilibrium effects, the focus here is on personal income and payroll taxes.

Consider a highly stylized economy in which there are three sectors: a sector in which labor and capital are subject to the full rates of payroll and income taxes; a sector that is for the most part legally exempt from taxation due either to explicit exemption from taxation, to the presence of extensive tax incentives (e.g., the offshore regime), or to the low effective rates of taxation under a simplified tax system; and a sector that is legally subject to full taxation but that illegally escapes all taxes because activities there are hard-to-tax (e.g., the shadow economy or an informal sector). If factors are mobile between these three sectors, then the imposition of payroll and income taxes in the taxed sector will cause labor and capital to respond by moving to the untaxed sectors. This movement will affect the wage of labor, the return to other factors of production, and the prices of consumer products. It will also influence the allocative effects of the taxes and the revenues that are collected.

To be more precise, let a stylized economy be divided into three sectors: a fully taxed sector that produces output (denoted $X$ ), a sector $(Y)$ that is legally exempt from (most) taxation, and a sector $(Z)$ that is legally subject to taxation but that illegally escapes taxation; for simplicity, assume that sector $Y$ is legally exempt from all taxes. Demand for each output is a function of relative prices, and all agents (including government) are assumed for simplicity to have the same average and marginal propensity to consume each commodity (e.g., there is a single "representative" consumer). Each good is produced under competitive conditions with a production function that depends upon the amount of capital $(K)$ and labor $(L)$. Capital and labor are assumed to be fixed in supply to the entire economy; they are also assumed to be perfectly mobile among the three sectors. Because of perfect mobility, net factor returns must be equalized across sectors, where factor returns are assumed to be adjusted for the presence of any risk premia that may exist. Since capital and labor in sectors $Y$ and $Z$ are assumed to be untaxed due either to legal avoidance or illegal evasion, there are only two effective taxes: a tax on capital $\left(T_{K}\right)$ and a tax on labor $\left(T_{L}\right)$ in the taxed sector $X$; the only other tax that might be imposed is a tax on consumption of $X$, a tax that is equivalent to an equal-rate tax on capital and labor in $X$. As discussed above, the taxation of labor (and capital) in only some uses creates an incentive for resources to flow from the taxed sector $(X)$ to the untaxed sectors $(Y$ and $Z)$. 
The full set of equations is presented in the Appendix. These equations are calibrated with data that capture the main characteristics of the Tunisian economy, so that its numerical solution can then be used to examine the economic impacts of changes in tax rates. It is this computable general equilibrium model that forms the basis for much of the following analysis of the economic effects of the tax system.

Tax Base Erosion. It is widely suspected that the structure of taxes gives both an incentive and an opportunity for individuals to escape the payment of taxes. There are several avenues that are available. One avenue is to move from the formal sector to the untaxed informal sector of the Tunisian economy. Another avenue is outright evasion of the legally due tax liability; indeed, there is a widespread perception that compliance with the income and payroll taxes, especially by the selfemployed, is very low. Still another, and legal, method of avoidance is for individuals to elect to be taxed under the simplified tax system or to take advantage of the incentive system.

Measuring the actual extent of this erosion via avoidance and evasion, and the associated revenue loss, is obviously quite difficult because there is little if any systematic information for Tunisia by which this notion can be tested. Tunisian government officials have suggested that the revenue loss due to evasion of the payroll programs themselves may be at least one-half of the actual collections from the programs, but this seems largely a guess, even if an informed one; officials make a similar estimate for the loss of personal income tax revenues.

The general equilibrium analysis suggests that taxes on the fully taxed formal sector $(X)$ reduce the size of the formal sector by somewhere between 5 and 12 percent, depending mainly upon the elasticity of demand for formal sector output, with most of the resources moving into the legally exempt sector $(Y)$. The resulting revenue loss also ranges from 5 to 12 percent.

These massive amounts of legal and illegal erosion compromise many dimensions of the fiscal system of Tunisia. Most obviously, base erosion leads to a loss in revenues, thereby affecting taxes that compliant taxpayers face and public services that citizens receive. Erosion creates misallocations in resource use when individuals and firms alter their behavior to evade or avoid their taxes and contributions. Its presence requires that government expend resources to deter noncompliance, to detect its magnitude, and to penalize its practitioners, even though these government enforcement activities seem infrequent and ineffective in Tunisia. Erosion alters the vertical and horizontal equity of taxation in unpredictable ways. Individuals with the same "true" level of income may pay very different amounts in taxes if some avoid/evade and others do not; individuals with different levels of "true" income may pay similar amounts of taxes even though their abilities to pay may differ greatly; and unless tax evaders are caught, evaders pay fewer taxes than honest taxpayers. Tax base erosion may contribute to feelings of unfair treatment and disrespect for the law, creating a selfgenerating cycle that feeds upon itself and leads to even more evasion. All of these results represent costs to the fiscal system of Tunisia.

Tax Incidence. In their entirety, the income and payroll taxes generate substantial revenues. Because these revenues must ultimately be paid by someone, they have a significant impact on the distribution of income; that is, who bears the burden of the taxes?

The general equilibrium model is used to examine the incidence of the taxes. Various numerical simulations of the model indicate that an increase in the tax rate on labor is shifted in part to capital (given that the taxed sector is assumed to be capital intensive) and in part to consumers of the taxed 
product (given that the labor tax increases the relative price of the taxed good). Even so, the main burden of any tax on labor (between 72 and 81 percent) is borne largely by labor in the form of a lower net-of-tax wage, which likely makes the overall burden of taxation regressive.

Allocative Effects. Taxes also affect the efficiency of resource use, or the "excess burden" of taxation. Measuring the excess burden requires knowledge of the responses of resources to the various taxes. This information can be generated from the general equilibrium model.

To illustrate, consider the tax on capital $\left(K_{X}\right)$ in sector $X$, or $T_{K}$. In the absence of the tax, factor mobility will assure that the equilibrium price of capital will be the same in both sectors. In the presence of the tax, however, capital will move from sector $X$ until the gross-of-tax price of capital in $X$ exceeds the price of capital in $Y$ and in $Z$ by the amount of the tax. Capital thus moves from higher productivity uses in the formal sector to lower valued uses in the informal sector. The excess burden of this single tax on capital in sector $X$ is measured by the usual welfare "triangle" of $(-1 / 2$ $\left.T_{K} \Delta K_{X}\right)$. When there are also taxes on labor in $X$ (or $L_{X}$ ), the combined excess burden becomes ($\left.1 / 2 T_{K} \Delta K_{X}-1 / 2 T_{L} \Delta L_{X}\right)$. Here, $\Delta K_{X}$ and $\Delta L_{X}$ represent the changes in factors that result from both taxes simultaneously. Estimation of the excess burden requires knowledge of these total factor responses. Assuming that the relevant derivatives are constant, the excess burden $E B$ is measured by:

$$
E B=-1 / 2 T_{K}\left[\left(\partial K_{X} / \partial T_{K}\right) T_{K}+\left(\partial K_{X} / \partial T_{L}\right) T_{L}\right]-1 / 2 T_{L}\left[\left(\partial L_{X} / \partial T_{K}\right) T_{K}+\left(\partial L_{X} / \partial T_{L}\right) T_{L}\right],
$$

where, for example, $\partial K_{X} / \partial T_{K}$ is the partial derivative of $K_{X}$ with respect to $T_{K^{\circ}}$. These partial derivatives allow for all general equilibrium adjustments in production and in demand, and so may be viewed as "reduced form" coefficients that show the equilibrium responses of capital and labor in the taxed sector to changes in the taxes. As in the case of the incidence of the payroll taxes, the solution of the system of equations allows these partial derivatives to be calculated directly, as functions of the amounts and the shares of capital and labor in the three sectors, the taxes on the factors in the taxed sector, and the various elasticities of demand and of substitution.

In all cases, the existence of a hard-to-tax sector, in combination with a legally untaxed sector, generates a large excess burden, somewhere between 11 and 27 percent of taxes and between 3 and 7 percent of formal sectors output. These estimates are especially sensitive to the compensated elasticity of demand for the taxed good. They are also somewhat sensitive to the various elasticities of substitution in production. They do not depend significantly on the assumption regarding the magnitude of tax evasion. It should also be remembered that there are many other sources of inefficiencies as well.

Sectoral, Occupational, and Employment Effects. Closely related to the incidence and the allocative effects of the taxes are their sectoral, occupational, and employment effects. The assumption that it is mainly workers in the formal sector of the Tunisian economy who bear the burden of the taxes does not allow for any shifting of the burden of taxes via adjustments in wages and other prices. As noted earlier, the existence of sectors to which resources may move to avoid the taxes means that these taxes drive a wedge between the returns to factors of production in the different sectors. If labor is mobile, then labor will respond to an increased tax in the formal sector by moving between the sectors until the net-of-tax return across the three sectors is equalized. This movement will affect the wages of labor in the three sectors, raising wages in the formal sector as labor flows from this sector and reducing wages in other two sectors as labor moves into these sectors. There will also be 
an impact on the returns to other factors and on product prices, as well as an impact on the overall unemployment rate.

Fully identifying these impacts requires a more detailed general equilibrium model of the economy than the one outlined earlier, one that allows for unemployment and that distinguishes labor types. However, there is some related work for other countries. For example, Alm and Lopez-Castano (2005) use a general equilibrium model of Colombia, in which the economy is divided into four sectors (farming, urban/informal, urban/unskilled, and urban/skilled) and which is calibrated with data from the 1999 social accounting matrix for Colombia. They find that the high rates of labor taxation lead to an overall increase in the number of unemployed workers, but also to an increase in employment in the informal sector. They also find that maintaining the level of expenditures of the programs financed by the taxes but changing the method of their finance to alternative revenues sources (e.g., deficit finance, company taxation) increases overall employment and formal sector employment.

Revenue Effects of Payroll Rate Reductions. A central issue in current discussions of Tunisia is the potential effect of payroll tax rate reductions on tax revenues. There are several ways of examining this issue. The simplest approach makes use of a basic accounting identity, in which tax revenues $R$ are equal to the product of the tax rate $t$, the number of individuals subject to the payroll taxes $N(t)$, and the value of the associated wage base $W(t)$, so that $R=t \cdot N(t) \cdot W(t)$. Both $N(t)$ and $W(t)$ are assumed to be functions of (among other things) the tax rate, to reflect the likelihood that changes in the tax rate affect the payroll tax base. The proportional change in revenues is then simply $\Delta R / R$ $=\Delta t / t+\Delta N / N+\Delta W / W$, so that the proportional change in revenues equals the sum of the proportional changes in the individual components. Recognizing that the number of individuals and the value of the wage base each depends upon the tax rate, the proportional change in revenues can also be written as $\Delta R / R=\Delta t / t\left(1+\varepsilon_{N, t}+\varepsilon_{W, t}\right)$, where $\varepsilon_{N, t}$ is the elasticity of the number of taxpayers with respect to the tax rate and $\varepsilon_{W, t}$ is the elasticity of the wage base with respect to the rate. Both elasticities will be negative in value because a reduction in tax rates will increase both $N$ and $W$.

Now suppose that the payroll tax rates are reduced by, say, 50 percent. In the absence of any change in the tax base, payroll tax revenues would fall, also by 50 percent. However, conversations with numerous government officials suggest that both $N(t)$ and $W(t)$ will respond to the rate reductions. If each variable increased by, say, 25 percent (or an elasticity in each case of $-1 / 2$ ), then overall revenues would be unchanged by the rate reduction. If the elasticities are greater than $-1 / 2$ (in absolute value), then revenues would actually increase. More generally, if the sum of the absolute values of the two elasticities exceeds unity, then a rate reduction would increase tax revenues.

The relevant issue then becomes the magnitude of the elasticities. There is no information on these elasticities. However, evidence for other types of responses in other countries suggests that elasticities in excess of $1 / 2$ (in absolute value) are extremely unlikely.

A slightly more complicated framework generates the same conclusion. Suppose that the equilibrium level of some tax base (e.g., the wages of workers subject to the labor taxes) depends upon the supply and the demand of this tax base. Then it is straightforward to show that the tax rate that maximizes the tax revenues collected from this tax base is $t_{\text {Maximum }}=\left(\varepsilon_{S}-\varepsilon_{D}\right) /\left(-\varepsilon_{D} \quad\left(1+\varepsilon_{S}\right)\right)$, where $t_{\text {Maximum }}$ is the revenue-maximizing tax rate, $\varepsilon_{S}$ is the elasticity of supply of the tax base, and $\varepsilon_{D}$ is the elasticity of demand, where both elasticities are assumed to be constant and where $\varepsilon_{S} \geq 0$ and $\varepsilon_{D} \leq 0$. Again, the crucial issue for the impact of any tax rate reduction is the magnitude of the elasticities. It 
is only when the elasticity of demand for the tax base exceeds - 1 (in absolute value) that there is any chance that a reduction in tax rates will increase revenues.

The general equilibrium model discussed earlier also gives the same conclusion. For reasonable values of the various elasticities, values that approximate estimates derived from empirical work on these behavioral responses, it is never the case that a decrease in the tax rate on labor increases tax revenues. The typical result is that a reduction in the labor tax rate generates some increase in labor in the taxed sector, but that this increase in labor (and the corresponding increase in labor tax revenues) is not nearly sufficient to offset the loss in revenues from the rate reduction. Indeed, for plausible values of the parameters, a reduction of, say, 10 percent in the labor tax rate reduces tax revenues in most scenarios by 5 to 9 percent. It is only when the various elasticities (especially the elasticities of substitution between labor and capital in the various sectors and the elasticity of demand for sector $X$ ) are extraordinarily high - and in excess of most all elasticities estimated from empirical work - that revenue simulations give the result that a reduction in the labor tax rate increases labor tax revenues. Recall also that the stylized model assumes that labor (as well as capital) is perfectly mobile across the taxed sector, the legally untaxed sector, and the evasion sector. When factor mobility becomes less than perfect, the possibility that a reduction in the tax rate increases tax revenues becomes even less likely. The results from other general equilibrium analyses generate similar conclusions (Alm and Lopez-Castano, 2005).

The Distorting Effects from Tunisia's System of Financial, Fiscal, and Other Incentives. The Tunisian system of incentives introduces a range of distortions in corporate behavior. However, measuring these distortions is quite difficult. In this section, several methods are used to suggest the magnitude of these efficiency losses.

One simple approach is to measure the average effective tax rate (AETR), calculated as total taxes actually paid as a fraction of gross corporate (accounting) income. If this measure differs across sectors and across asset types - as it likely does in Tunisia - then these differences give an indication of the ways in which the corporate income tax (together with all of its special provisions) creates incentives for resources to move between sectors and assets, thereby creating distortions in the allocation of resources.

Another approach is to calculate the marginal effective tax rate (METR) (Boadway, Bruce, and Mintz, 1984). METRs attempt to measure the impact of taxes on the marginal (or incremental) decision by economic agents to invest in capital. The METR is defined as the additional tax paid by a firm when it decides to invest in one more unit of capital. A positive METR indicates that investment is discouraged; a negative METR indicates that investment is subsidized even in the presence of the corporate income tax via such special provisions as accelerated depreciation, investment tax credits, tax holidays, and the like. METRs can be calculated by sector and also by asset types. Differences in METRs across sectors and across assets generate incentives for resources to reallocate due entirely to tax considerations, and therefore create efficiency losses.

The premise underlying METR calculations is that the gross rate of return on capital (net of economic depreciation) for a profit-maximizing firm must be equal to the financing cost of capital, adjusted for taxes. The size of this adjustment for taxes on a new investment is the marginal effective tax rate on capital; that is, the METR is the difference between the pre-tax rate of return on a marginal investment, or the gross rate of return on investment) and the required post-tax rate of return, expressed as a percentage of pre-tax rate of return. 
More precisely, the marginal effective tax rate on a given type of capital investment is defined as the proportional difference between the gross-of-tax rate of return required by a firm $r^{G}$ and the net-oftax rate of return required by an investor $r^{N}$, where $r^{G}$ is the difference between the marginal revenue product (or "user cost" of capital) and economic depreciation and the after-tax rate of return is the weighted average of the return to debt and equity held by the investor. Thus, the marginal effective tax rate is defined as:

$$
\operatorname{METR}=\left(\mathrm{r}^{\mathrm{G}}-r^{\mathrm{N}}\right) / r^{\mathrm{G}} \text {. }
$$

For example, if the gross-of-tax rate of return to capital is 20 percent and the net-of-tax rate of return is 10 percent, then the METR on capital is 50 percent.

Note that both methods may accurately capture the effective tax rates on those businesses that actually pay taxes. However, both methods are almost certain to overstate - perhaps quite significantly - the overall average effective tax rates on all businesses, including those that comply and those that do not comply. The widespread existence of tax evasion means that many businesses face an effective tax rate (marginal or average) of zero.

The detailed information needed to calculate these AETRs and METRs for more specific industry/asset classifications is not yet available. Even so, it seems likely that these calculations would reveal greatly different rates of taxation by sector and by asset type, both of which contribute to the distorting effects of the Tunisian incentives system.

\section{Box 2. A Numerical Example of Calculating Marginal Effective Tax Rates}

The calculation of a marginal effective tax rate (METR) for a hypothetical industry $\mathrm{X}$ in Tunisia and its assets is explained here using a numerical example. Assume that there are domestic investors (Tunisia) as well as foreign investors, where the foreign investors are assumed to be from the United States. Assume also that the following values hold for important tax parameters in hypothetical industry $\mathrm{X}$, as given in Box Table I:

\section{Box Table I: Tax Parameters (in percent except last three rows)}

\begin{tabular}{|l|c|c|}
\hline \multirow{2}{*}{ Tax Parameter } & \multicolumn{2}{|c|}{ Investor } \\
\cline { 2 - 3 } & U.S. & Tunisia \\
\hline Statutory CIT Rate & 34 & 30 \\
Tax on Transfer of Property, Import Duty on Capital Goods & $*$ & 5 \\
Capital Tax Rate & $*$ & 0 \\
Tax Depreciation Rate-Building & $*$ & 10 \\
Tax Depreciation Rate-Machinery & $*$ & 15 \\
Property Tax Rate & $*$ & 5 \\
Gross Receipt Tax Rate or Presumptive Tax & $*$ & 0.5 \\
Sales Tax Rate & $*$ & 15 \\
Present Tax Value of Accumulated Capital Cost Allowance for Building & $*$ & 0.093 \\
Present Tax Value of Accumulated Capital Cost Allowance for Machinery & $*$ & 0.107 \\
FIFO=1 and LIFO=0 & 0 & 1 \\
\hline
\end{tabular}

where * denotes that this parameter is not used in the calculations. In most cases, the values in the table are those applicable for Tunisia. The present tax value of accumulated capital cost allowance for buildings and machinery has been calculated assuming a 50 percent allowance in the first year and declining depreciation from the next year. The same values of taxes (e.g., those levied in Tunisia) are assumed to apply to both the domestic and the foreign (U.S.) investor. Non-tax parameters are given in Box Table II: 
Box Table II: Non-tax Parameters (in percent)

\begin{tabular}{|l|c|c|}
\hline Non-tax Parameter & U.S. & Tunisia \\
\hline Expected Inflation Rate & 2.40 & 4.57 \\
Expected Real Interest Rate & 3.1 & 6.0 \\
Cost of Equity & 6.89 & 6.89 \\
Debt to Assets Ratio & & \\
Debt Raised Abroad to Home Capital & 40 & 40 \\
Debt to Asset Ratio in Home Country & 40 & 40 \\
Rate of Economic Depreciation & & \\
Building & $*$ & 2 \\
Machinery & $*$ & 5 \\
\hline
\end{tabular}

The first stage in the calculation of the METR for an industry is the computation of the real cost of financing. Using the formulae given in equations (2) and (2') in Appendix II, the real cost of financing for domestic and foreign investors, respectively, is calculated. These calculations give 2.3 percent and 3.6 percent, respectively.

The second stage in the calculation is the computation of the net-of-tax rate of return. Using equations (3) and ( $\left.3^{\prime}\right)$ in Appendix II, for domestic and foreign investors as before, the net-of-tax rate of return on capital is calculated for each category of assets (building, machinery, inventory, and land). See Box Table III.

Box Table III: Rate of Return on Capital (percent)

\begin{tabular}{|l|c|c|}
\hline Rate of Return on Capital & U.S. & Tunisia \\
\hline Net-of-tax Return & 4.61 & 3.83 \\
Gross-of-tax Return & & \\
Building & 6.60 & 4.73 \\
Machinery & 8.04 & 6.20 \\
Inventory & 6.24 & 6.93 \\
Land & 6.06 & 4.00 \\
\hline
\end{tabular}

The third stage in the calculation is the computation of the gross-of-tax rate of return on capital; these are calculated using equations (4) and (4') in Appendix II, separately for domestic and foreign investors. Given the assumed values above, the net-of-tax and gross-of-tax rates of return are in Box Table III:

In the final stage, the marginal effective tax rate for each type of asset using the two rates of return is calculated as: $\operatorname{METR}=\left(r_{g}-r_{n}\right) / r_{g}$.

Based on the above assumptions and calculations, the results for industry $\mathrm{X}$ are in Box Table IV. The total METR for industry $\mathrm{X}$ is the weighted average of the METR by asset type, where we assume that the value of each asset type in the industry is: building 30 percent; machinery 50 percent; inventory 10 percent; and land 10 percent.

Box Table IV: METRs (percent)

\begin{tabular}{|l|c|c|}
\hline METR & U.S. & Tunisia \\
\hline Building & 30 & 19 \\
Machinery & 43 & 38 \\
Inventory & 26 & 44 \\
Land & 24 & 4 \\
\hline Industry X & $\mathbf{3 6}$ & $\mathbf{3 2}$ \\
\hline
\end{tabular}


The Tax Burden on Labor. There is little question that labor is taxed relatively heavily in Tunisia. As documented earlier, personal income tax rates (and, to a somewhat lesser extent personal income tax revenues) tend to be higher in Tunisia than in many other countries. Social Security contributions also increase significantly the burden on labor. In both cases, this burden is felt especially by labor in the formal sector of the economy.

An additional measure of the tax burden on labor is given by the "tax wedge", which is a measure of the difference between labor costs to the employer and the corresponding net take-home pay of the employee. The tax wedge is calculated by taking the sum of the personal income tax rate, the employee plus employer Social Security contributions rate (together with any payroll tax), minus any benefits to which contributions entitle the worker, and expressing this as a percentage of labor costs. The average tax wedge therefore identifies that part of total labor costs that are taken in tax and Social Security contributions net of cash benefits.

Table 9 presents recent (2011) estimates of the tax wedge for OECD countries, in descending order of the size of the tax wedge. Preliminary calculations for an average income, full-time worker in Tunisia indicate a relatively higher tax wedge, at 39.1 percent, in Tunisia.

\section{Evaluating the Tunisian Tax System}

Tax systems are designed to achieve multiple objectives. An obvious purpose is to raise the revenues necessary to finance government expenditures (sometimes termed "adequacy"), and also to ensure that the growth in revenues is adequate to meet expenditure requirements ("elasticity"). Another is to distribute the burden of taxation in a way that meets with a society's notions of fairness; such "equity" is typically defined in terms of "ability to pay", such that those with equal ability should pay equal taxes ("horizontal equity") and those with greater ability should pay greater taxes ("vertical equity"). Taxes can also be used to influence behavior of those who pay them; in choosing taxes, a common goal is to minimize the interference of taxes in the economic decisions of individuals and firms. Taxes should be simple, both to administer and to comply with because a complicated tax system wastes the resources of tax administrators and taxpayers. Consider now the performance of the Tunisia tax system in achieving these objectives.

There are large amounts of tax evasion. By all accounts, there are large amounts of income and consumption that escape taxation in Tunisia. Firm evidence on evasion is obviously difficult to find. Even so, estimates of the size of the "underground economy" (or all market-based goods and services, legal or illegal, that escape inclusion in official accounts) in Tunisia are also quite large. For example, Alm and Embaye (2013) estimate that the current size of the Tunisian underground economy is 32 percent, down from an estimated 45 percent in 1984. See Tables 10.

There is a narrow and shrinking tax base. The goal of most tax reforms is to broaden the tax base, thereby allowing marginal tax rates to be reduced. However, the tax base in Tunisia has been narrowed in at least two important ways. One is legal and takes the form of exemptions or preferential treatment (e.g., "tax expenditures"), especially via the extensive system of incentives. To our knowledge, there is no systematic listing of the tax expenditures in the Tunisia tax system, which in itself is a problem. The second stems from administrative failures (especially enforcement problems) that allow the existence of enormous amounts of tax evasion. 
One result of a small and falling tax base is that the government must emphasize collection of taxes from those "tax handles" that are more readily available. More visible taxpayers (such as labor in the formal sector) end up bearing increasing amounts of the tax burden.

There is widespread use of fiscal, financial, and other incentives. The use of incentives, especially in the corporate income tax, is widely acknowledged.

A common argument is that, without these incentives, Tunisian firms simply cannot compete in the world economy. A counterargument is that incentives (and the resulting preferential tax treatments) have created a misallocation of investment that has led in turn to a loss in competitiveness. Also, there is little question that incentives are a significant fiscal drain on the budget, a cost that can be reflected in higher taxes on labor or in public investments that have been forgone.

Still, the crucial issue is: Why give these incentives? The main reason appears to be that many countries believe that they must have the incentives to compete with rival countries, especially when the country has little in the way of market size or resource endowment to attract foreign investors. Put differently, the introduction of a fiscal, financial, or other incentive type by one country leads to strategic responses by other, rival countries. A related reason is that the introduction of incentives also stems from the power of large domestic firms, who pressure the government to take measures that favor their enterprises. In both cases the result is the same: the incentives have little impact on investment because other countries have similar incentives, but the incentives have a large and negative impact on the tax collections of all countries and simply transfer revenues to large enterprises.

Even so, it is important to consider - and quantify - the benefits and costs of incentives. The possible benefits to a country that offers incentives may include increases in investment, gains from industrialization, the creation of jobs for persons who otherwise would be unemployed or employed at lower wages, the transfer of technology and training, and increases in revenues from taxes to which the incentives do not apply or from taxes payable after the initial reduction has ended. It is interesting that few countries have actually undertaken a rigorous analysis of these benefits. Overall, there is very little evidence that incentives are able to attract or to induce investment that would not have been undertaken anyway.

As for the costs, these include the loss of revenue, distortions in investment behavior leading to investments that are socially unproductive, administrative complications, political discord generated by favors to foreign-owned corporations, and discrimination against smaller firms that lack the resources and/or the influence to apply for the incentives.

The actual evaluation of benefits and costs has seldom been done. In one instance (Thirsk, 1991), the benefits in Jamaica were generally found to be positive but small, and smaller than their costs. In another instance, Indonesia eliminated all of its investment incentives as part of a comprehensive tax reform in the mid-1980s (Gillis, 1985), because there was much evidence that few if any incentives had the desired effects in attracting desired investments, that their administrative problems were enormous (especially for tax holidays), that they significantly distorted investment patterns, and that generated massive losses in tax revenues. On balance, these costs were deemed to be far in excess of the potential benefits. The conclusion in Indonesia was that the best policy for investment was deemed to be a reduced overall rate of taxation in the corporate income tax. 
Indeed, there is now some evidence that the best way to encourage investment is simply to lower the tax rate in the corporate income tax, not to offer targeted incentives, since there is little evidence that incentives are more important to potential investors than such factors as political stability, potential market size, economic growth, or infrastructure There is also increasing evidence that the main effect of incentives is to shift income across jurisdictions (via such mechanisms as transfer pricing and financial policies) rather than to stimulate real activity in jurisdictions. In short, the main messages of this research are that incentives can stimulate investment, but that a country's overall economic characteristics are much more important than any incentives package both for the success or the failure of industries and as potential "drivers" of investment decisions by long-term investors (Hines, 2007). Moreover even if/when incentives stimulate some additional investment, they are not generally cost-effective. Again, this is not to deny that incentives can affect the movement of "capital", broadly defined. It is to question whether any such movement represents a transfer of "real" economic activity as opposed to simply a transfer of "paper" transactions that reduce a firm's tax liabilities without generating any real economic activity. It is also to question whether the benefitcost ratio of any such incentive is greater than one. Overall, then, in the few instances in which detailed analyses have been performed, the benefits of incentives are less than their costs.

There are significant limitations in tax administration. A dominant theme in most assessments of the Tunisia tax system is the absence of effective tax administration. If taxes cannot be administered efficiently and equitably, then the goals of any tax reform will not be achieved. As noted by Surrey (1958), "...the concentration on tax policy on the choice of taxes may lead to insufficient consideration of the aspect of tax administration. In short, there may well be too much preoccupation with 'what to do' and too little attention to 'how to do it." Put differently, tax administration should be placed at the center, not the periphery, of tax reform efforts (Bird and Casanegra de Jantscher (1992).

One indicator of administrative efficiency is the extent of tax evasion. As discussed earlier, there are apparently large amounts of evasion in Tunisia, with a wide range of negative effects. Evasion reduces the revenue and the elasticity of the tax system. It necessarily undermines the horizontal and vertical equity of the tax system, since equals are no longer taxed equally and the well-to-do are generally more successful in exploiting opportunities for evasion. The actual allocative effects of the tax system are likely to differ significantly from those implied by the statutes. In short, poor tax administration frustrates the achievement of all goals of taxation.

Other problems with the tax administration stem from the tax structure: the tax base has been narrowed by preferences, the system is overly complex, especially in its use of fiscal, financial, and other tax incentives, and over time the rate and base structures have become more and more complex, as discussed next. The structural and administrative problems are clearly related. Complexity in the rate and base structure makes administration more difficult and also reduces the compliance rate.

A vital issue in tax administration is the current absence of field audits. The effectiveness of any move toward self-assessment is likely to be compromised by the absence of audits. In the absence of an effective audit system, it is especially important to have in place a comprehensive system of withholding.

The tax system is excessively and unnecessarily complex. The limitations in tax administration are magnified by the overly complex tax system. Over time, the tax system has been adjusted to raise 
revenue, or to respond to requests for more favorable tax treatment, or to promote specific activities, or to redistribute income, or to protect the poor. Each of these changes likely complicates the tax system. Complexity in turn leads to higher administrative costs, more arbitrariness in administration, and an increasing erosion of confidence in the fairness and effectiveness of the tax system. Taxpayers are not inclined to pay a tax that they do not understand, that imposes high compliance costs, and that is administered by a tax administration that is viewed as arbitrary and ineffective.

There are numerous elements that complicate the tax system. Sometimes complication is a byproduct of well-intentioned adjustments to the tax structure (e.g., the exemption of the purchases of items consumed by lower income individuals). Also, the corporate income tax in Tunisia, like that in most countries, is excessively complicated, especially given the heavy use of incentives.

Still, there are areas where the system is needlessly complex. Clearly this is true for fiscal, financial, and other incentives. It may also be true for depreciation provisions.

All taxes impose compliance costs on taxpayers and administrative costs on government. Taxpayer compliance costs include time spent keeping receipts, logging appropriate books, and filing tax returns. Administrative costs include assessment, audit, and collection. Some taxes are less expensive to administer and to comply with than other taxes. This is due to such factors as the complexity of particular tax laws, the familiarity of taxpayers with various taxes, the process by which taxes are collected, and the status of data collection, enforcement, and monitoring for the various taxes. For example, taxes that are subject to source withholding are less costly to administer than taxes that require individual filing.

It is difficult to quantify the costs of administration and compliance across countries. However, there is some work that has calculated these costs, using a variety of methods. These studies demonstrate that there is substantial variation in the compliance and administrative costs across taxes and countries. Income taxes appear to be especially high in terms of administrative costs per dollar of revenue collected, with the more complicated the system the higher the cost. Broaderbased taxes may be less costly to administer, but capital gains taxes are notoriously difficult to administer.

There are no data on compliance and administrative costs in Tunisia, so it is not possible to directly compute these costs. However, it seems likely that Tunisia's tax structure is a high-cost one. There is an inordinately high reliance on direct taxes, there is much less use of indirect taxes, the structure of the corporate income tax in Tunisia is very complex, and there is extensive use of incentives. All of these factors imply higher compliance and administrative costs than would be the case for a less complicated system and one that relies more on indirect taxes.

There are horizontal and vertical inequities in taxation, but these inequities are not quantified. There is little question that the practice of taxation in Tunisia introduces significant vertical and horizontal inequities. Unfortunately, little is known about the overall fairness of Tunisia's tax system; that is, who pays taxes in Tunisia, and how does the tax system affect the distribution of income? This lack of precise information has not stopped a general perception that Tunisia's tax system is regressive.

In a "fair" tax system, equally-situated individuals and companies will face the same tax obligations (i.e., "horizontal equity"). When this is not the case, some individuals will bear a heavier burden than 
others with comparable means. This weakens confidence in the system, and encourages taxpayers to look for avenues of nonpayment that will have negative consequences for revenues. It also may lead individuals and companies to make different economic choices in order to capture tax advantages, which in turn leads to economic inefficiencies.

Indeed, there are many sources of horizontal inequities in the Tunisian tax system:

- Individuals who work in the formal sector of the Tunisia economy are subject to employer withholding on their wage income, while those who are self-employed or who work in the informal sector are less likely to pay the personal income tax. The result can be very different tax burdens, even for individuals with the same "true" income.

- Individuals differ in their opportunities for tax evasion, especially between the formal sector and the informal sector.

- Some individuals receive non-taxable benefits from their employer while others do not receive them or receive them at a lower rate. Again, the result can be very different tax burdens for households with equal income.

- Some consumers face very different effective indirect tax rates than others, given the uneven pattern of exemptions on the excises.

- The corporate income tax discriminates among firms, largely because of the existence of incentives and other tax preferences that are available to some firms, sectors, and asset types, and not to others.

- In addition to the formal provisions for tax relief, there seems to be discretionary relief on a case-by-case basis.

The horizontal inequity that may be the most contentious in Tunisia is that between workers subject to income tax withholding and workers in the self-employed sector. Again, this factor contributes to an especially heavy burden on formal sector labor.

Note that, if a tax system is "fair", individuals with greater ability to pay will pay greater amounts of taxes, as reflected in different effective tax rates by income class (i.e., "vertical equity"). However, these sources remain largely unexamined.

There are large efficiency costs of Tunisian taxes. As demonstrated by the general equilibrium calculations of excess burden discussed earlier, the system of taxes in Tunisia is introduces a wide range of distortions in individual and firm behavior, all of which generate significant efficiency costs. For example, the corporate income tax generates many distortions, perhaps more than any other tax in the system. Together with the extensive system of incentives, the corporate tax gives preferential treatment both to different types of investment and to different sectors, thereby leading firms to base their investment decisions mainly on tax considerations rather than on market forces. As discussed earlier, the use of tax incentives to increase investment and to generate growth is a questionable and unproven practice. The personal income tax also generates distortions: it discourages work effort, it reduces the return to savings, and it encourages individuals to move to the informal sector. The simplified tax system also leads to distortions. Unfortunately, there are no estimates of the overall efficiency cost of Tunisia taxes.

The current system is an outdated and an ad hoc system. Tunisian tax policy has, apparently and increasingly, become focused on accommodating the requests of specific individuals and of specific sectors of the economy. A move away from a transparent and rule-based approach to one with 
many preferential treatments has harmed the fairness of the system, has increased its distortions, and has increased the burden on taxpayers and tax administrators alike.

It is tempting to assume that favored tax treatments result from pressure from special interest groups. While some of this may go on, the Tunisia government is also likely - for good reasons - to reduce the tax on certain items of necessary consumption in order to help the poor or other target groups, or to reduce the tax on certain types of investments in order to encourage investments that the government considers worthwhile. Regardless of the motivation, however, these policies affect the fairness of the tax system, they lead others to clamor for favorable treatment, they make the system less transparent and more complex, and they lead to unintended and unforeseeable consequences. They also cause a revenue loss that must be made up by higher taxes on other sectors of the economy, and they may well generate corruption.

\section{Reforming Tunisia's Tax System}

There may well be a case for a comprehensive reform of the Tunisian tax system, along the standard lines of broadening the bases of taxation and reducing the rates of taxation. However, a comprehensive reform requires a major effort to study the entire system and to consider the major alternatives. This effort takes considerable time. In the meantime, there are several more incremental reforms that would improve the operation of the Tunisian economy. Potential reform measures include several specific recommendations.

Expand the base of indirect taxes. The bases of indirect taxes have often been narrowed by deliberate policy choices. Broadening the bases will mean mainly two things. The first is fully extending taxes into the service sector. The second is simplifying and reducing existing exemptions and special treatment regimes after a thorough review of these exemptions. When outright elimination is not feasible, the exemptions may be phased out by not renewing them.

Increase VAT tax rates. The standard VAT tax rate (18 percent) is comparable (if slightly higher than) the standard rate in many countries. However, the preferential rates of 6 and 12 percent are quite low. These could be increased, even standardized, with little impact on competitiveness.

Reduce the use of fiscal, financial, and other incentives. As discussed in detail earlier, these incentives reduce revenues, distort resource allocation, and introduce inequities, with little if any documented impact on intended activities. Their use should be significantly reduced.

Reduce personal income and/or Social Security contribution rates. There is abundant evidence that labor, especially in the formal sector, is heavily taxed. Reducing taxes on labor (with offsetting increases in indirect taxes) would have many positive economic effects.

Consider reforms of Le Regime Forfaitaire. There are several specific reforms of the simplified tax system that should be considered, such as: ensuring that the tax burdens under the simplified tax system and under the regular tax system are comparable; reevaluating turnover thresholds, so as to ensure that only "small" taxpayers are eligible for the simplified system; adjusting the thresholds for inflation and other changing economic circumstances; and improving enforcement of the simplified tax system to ensure that individuals who participate are in fact eligible for participation and also to prevent purely artificial accounting schemes that allow participation. 
Alm, WP 34, May 2015

Increase enforcement effort and other administrative reforms. It is especially important to increase audit activities. World-wide experience also demonstrates that greater use of third-party information is an effective tool in compliance efforts. Finally, efforts to modernize tax administration have been shown to have a significant even if longer-term payoff. 
Alm, WP 34, May 2015

\section{References}

Alm, J., \& Embaye, A. (2013). Using dynamic panel methods to estimate shadow economies around the world, 1990-2006. Public Finance Review, 41 (5), 510-543.

Alm, J., \& Lopez-Castano, H. (2005). Payroll Taxes in Colombia. In Fiscal Reform in Colombia Problems and Prospects, Bird, R., Poterba, J., \& Slemrod, J. (Eds.). Cambridge, MA: The MIT Press, 191-223.

Alm, J., Martinez-Vazquez, J., \& Wallace, S. (2004). Taxing the Hard to Tax: Lessons from Theory and Practice. Amsterdam, The Netherlands: Elsevier B.V.

Bird, R., \& Casanegra de Jantscher, M. (Eds.) (1992). Improving Tax Administration in Developing Countries. Washington, D.C.: International Monetary Fund.

Boadway, R. Bruce, N., \& Mintz, J. (1984). Taxation, inflation, and the effective marginal tax rate in Canada. Canadian Journal of Economics, 27 (3), 286-299.

Gillis, M. (1985). Micro and macroeconomics of tax reform in Indonesia. Journal of Development Economics, 19 (3), 221-254.

Hines, J. R., Jr. (2007). Corporate taxation and international competition. In Taxing Corporate Income in the $21^{\text {st }}$ Century, Auerbach, A. J., Hines Jr., J. R., \& Slemrod, J. (Eds.). Cambridge, UK: Cambridge University Press, 268-295.

Martinez-Vazquez, J., \& McNab R. (2000). The tax reform experiment in transitional countries. National Tax Journal, 53 (2), 273-298.

OECD (2012). Taxing Wages, 2011. Paris, France: Organisation for Economic Co-operation and Development Publishing.

Peter, K. S., Buttrick, S., \& Duncan, C. (2010). Global reform of personal income taxation, 1981 2005: Evidence from 189 countries. National Tax Journal, 63 (3), 447-478.

Surrey, S. S. (1958). Tax administration in underdeveloped countries. University of Miami Law Review, $12(2), 158-188$.

Thirsk, W. (1991). Jamaican tax incentives. In The Jamaican Tax Reform, Bahl, R. (Ed.). Cambridge, MA: Lincoln Institute of Land Policy, 701-725.

World Bank (2010). Doing Business, 2010 - Reforming through Difficult Times. Washington, D.C.: The World Bank and the International Finance Corporation.

World Bank (2012). Doing Business, 2012 - Doing Business in a More Transparent World. Washington, D.C.: The World Bank and the International Finance Corporation. 


\section{Appendix: Equations of General Equilibrium Model}

The full set of equations for the stylized economy can be represented as follows (where ${ }^{\wedge}$ denotes the percentage change in the relevant variable):

$$
\begin{aligned}
& \left.\hat{X}=E_{X X} \hat{P}_{X}-\hat{P}_{Z}\right)+E_{X Y}\left(\hat{P}_{Y}-\hat{P}_{Z}\right) \\
& \hat{Y}=E_{Y X}\left(\hat{P}_{X}-\hat{P}_{Z}\right)+E_{Y Y}\left(\hat{P}_{Y}-\hat{P}_{Z}\right) \\
& \hat{X}=f_{K} \hat{K}_{X}+f_{L} \hat{L}_{X} \\
& \hat{\mathrm{Y}}=g_{K} \hat{K}_{Y}+g_{L} \hat{L}_{Y} \\
& \left.\hat{K}_{X}-\hat{L}_{X}=s_{X} \hat{(r}+T_{K}-\hat{w}-T_{L}\right) \\
& \hat{K}_{Y}-\hat{L}_{Y}=s_{Y}(\hat{w}-\hat{r}) \\
& \hat{K}_{Z}-\hat{L}_{Z}=s_{Z}(\hat{w}-\hat{r}) \\
& \hat{K}_{X} K_{X}+\hat{K}_{Y} K_{Y}+\hat{K}_{Z} K_{Z}=0 \\
& \hat{L}_{X} L_{X}+\hat{L}_{Y} L_{Y}+\hat{L}_{Z} L_{Z}=0 \\
& \left.\hat{P}_{X}=f_{K}\left(r+T_{K}\right)+f_{L} \hat{(w}+T_{L}\right) \\
& \hat{P}_{Y}=\hat{g_{K} r}+g_{L} \hat{w} \\
& \hat{P}_{Z}=\hat{h_{K} r}+h_{L} \hat{w} \\
& \hat{P}_{Z}=0
\end{aligned}
$$

where $E_{i j}$ is the compensated elasticity of demand for $i$ with respect to a change in the price of good $j$, defined to be nonpositive $(i, j=X, Y) ; P_{i}$ is the price of $\operatorname{good} i(i=X, Y, Z) ; r$ is the price of capital; $w$ is the price of labor; $f_{j}$ is the initial share of factor $j$ in sector $X(j=K, L) ; g_{j}$ is the initial share of factor $j$ in sector $Y(j=K, L) ; h_{j}$ is the initial share of factor $j$ in sector $Z(j=K, L) ; s_{i}$ is the elasticity of substitution between capital and labor in sector $i$, defined to be nonpositive $(i=X, Y, Z)$; and $T_{j}$ is the tax on factor $j$ in sector $X(j=K, L)$.

Equations (1) and (2) express the percentage change in compensated demand as a function of the percentage change in the relative product prices of $X$ and $Y$, respectively. Equations (3) and (4) describe the change in output of $X$ that results from changes in factor usage in the sector. Equations (5), (6), and (7) relate the change in factor proportions in the sectors to changes in relative factor prices via the elasticity of substitution in production. Equations (8) and (9) follow from the assumption of fixed factor supplies of capital and labor. Equations (10), (11), and (12) show the relationships between changes in factor prices (including taxes where appropriate) and the resulting changes in product prices. Equation (13) defines the price of good $Z$ as the numeraire. All physical units are chosen such that initial prices are unity.

These equations constitute a thirteen-equation, thirteen-unknown system, where the unknowns are $\hat{\mathrm{X}}, \hat{\mathrm{Y}}, \hat{\mathrm{K}}_{\mathrm{X}}, \hat{\mathrm{K}}_{\mathrm{Y}}, \hat{\mathrm{K}}_{\mathrm{Z}}, \hat{\mathrm{L}}_{\mathrm{X}}, \hat{\mathrm{L}}_{\mathrm{Y}}, \hat{\mathrm{L}}_{\mathrm{Z}}, \hat{\mathrm{P}}_{\mathrm{X}}, \hat{\mathrm{P}}_{\mathrm{Y}}, \hat{\mathrm{P}}_{\mathrm{Z}}, \hat{\mathrm{r}}$, and $\hat{\mathrm{w}}$. This system can be reduced by substitution and then solved for the remaining unknowns by Cramer's Rule. 
Using dollars as the unit of currency for purposes of discussion, the size of sector $X$ is assumed to equal $\$ 75$, and this also equals the sum of the gross-of-tax income of capital and labor in the sector. Similarly, sector $Y$ is assumed to equal $\$ 25$; the legally untaxed sector $Y$ is therefore $1 / 3$ the size of the taxed sector. The amounts paid gross-of-tax to $K$ and $L$ in the taxed sector are assumed to equal $\$ 20$ and $\$ 55$, respectively, so that the shares of capital and labor in sector $X$ (denoted $f_{K}$ and $f_{L}$ ) are assumed to equal $f_{K}=0.2667$ and $f_{L}=0.7333$. The amounts paid to $K$ and $L$ in sector $Y$ are assumed to equal $\$ 5$ and $\$ 20$, respectively. The factors shares in sector $\mathrm{Y}\left(\mathrm{g}_{K}, g_{L}\right)$ are therefore $g_{K}=0.2$ and $g_{L}$ $=0.8$.

Recall that units are chosen so that one unit of a factor is the amount that earns $\$ 1$ net of taxes. Because capital and labor in sector $Y$ are not taxed, there are 5 units of capital and 20 units of labor in the sector. For sector $X$, we assume that total taxes equal 25 percent of output in sectors $X$ and $Y$, with $\$ 8$ of taxes coming from capital in sector $X$ and $\$ 17$ coming from labor in $X$. Because units of capital and labor are chosen so that one unit of a factor is the amount that earns $\$ 1$ unit net of all taxes, there are $12(=20-8)$ units of capital in $X$ and $38(=55-17)$ units of labor. This procedure also generates estimates of the tax rate on capital and labor. The tax rate is calculated by dividing the total taxes borne by the factor by its net-of-tax income. The tax rate on capital in sector $X$ is 0.6667 $(=\$ 8 / \$ 12)$, while the tax rate on labor is $0.4474(=\$ 17 / \$ 38)$. Capital and labor in sector $Y$ are untaxed.

As for the hard-to-tax sector $Z$, two alternative assumptions are made about its size: sector $Z$ equals either 25 percent of formal sector $(X+Y)$ output, or $\$ 25$, or it equals 50 percent $(\$ 50)$ of formal sector output. In either case, this sector is assumed to be highly labor-intensive, with factor shares for labor $\left(h_{L}\right)$ and capital $\left(h_{K}\right)$ of $h_{L}=0.9$ and $h_{K}=0.1$, respectively. Sensitivity analysis indicates that the resulting estimates do not vary substantially with variations in the size of the sector.

Various combinations of the elasticities of substitution between capital and labor (or $s_{i}, i=X, Y, Z$ ) are assumed, from 0 to $-1 / 2$ to -1 . As for the compensated elasticities of demand, the own-elasticities $\left(E_{X X}, E_{Y Y}, E_{Z Z}\right)$ are assumed to equal each other, and the cross-elasticities of demand of $Y$ and $Z$ with respect to the price of the taxed good $X$ are assumed also to equal one another. Together with the requirement of symmetry in compensated responses, these assumptions imply that choosing a value for $E_{X X}$ determines the values of the other elasticities. We assume that $E_{X X}$ equals $-1 / 2$ or -1 . Variations in the elasticities of demand and of substitution have a more significant impact on the estimates. 
Alm, WP 34, May 2015

Table 1. Composition of Consolidated Central Government Revenues for Tunisia (in millions of TND)

\begin{tabular}{|c|c|c|c|c|c|c|c|c|c|c|c|}
\hline & 2000 & 2001 & 2002 & 2003 & 2004 & 2005 & 2006 & 2007 & 2008 & 2009 & 2010 \\
\hline Taxes & 5678.4 & 6221.5 & 6429.1 & 6630.8 & 7252.0 & 7904.2 & 8469.8 & 9508.1 & 11330.9 & 11763.7 & 12738.9 \\
\hline Taxes on income, profits, and capital gains & 1596.8 & 1827.7 & 2024.3 & 2176.9 & 2385.2 & 2886.2 & 3106.7 & 3697.7 & 4560.9 & 4645.5 & 5047.4 \\
\hline Personal Income Tax & 1021.8 & 1152.8 & 1213.6 & 1309.0 & 1436.8 & 1524.2 & 1716.8 & 1948.8 & 2145.3 & 2379.0 & 2614.4 \\
\hline Corporate Income Tax & 575.0 & 674.9 & 810.7 & 867.9 & 948.4 & 1362.0 & 1389.9 & 1748.9 & 2415.6 & 2266.5 & 2433.0 \\
\hline Taxes on payroll and workforce & 106.7 & 107.8 & 80.8 & 118.4 & 121.1 & 114.2 & 137.1 & 148.6 & 142.7 & 170.9 & 199.0 \\
\hline Taxes on property & 121.3 & 134.0 & 138.9 & 135.6 & 148.7 & 169.6 & 206.7 & 216.8 & 237.4 & 264.1 & 280.3 \\
\hline Taxes on goods and services & 2903.6 & 3157.1 & 3239.3 & 3359.8 & 3690.1 & 3836.8 & 4056.9 & 4373.2 & 5061.2 & 5377.3 & 5775.2 \\
\hline VAT & 1929.7 & 2087.2 & 2103.2 & 2170.8 & 2426.7 & 2482.9 & 2652.8 & 2864.4 & 3480.9 & 3636.9 & 4031.3 \\
\hline Excises & 790.6 & 865.5 & 914.2 & 954.2 & 1020.6 & 1050.5 & 1074.5 & 1149.7 & 1201.9 & 1260.8 & 1298.8 \\
\hline Taxes on international. trade and transactions & 833.6 & 875.5 & 790.8 & 725.9 & 752.3 & 735.1 & 758.0 & 825.7 & 965.0 & 987.6 & 1142.6 \\
\hline Other taxes & 116.4 & 119.4 & 155.0 & 114.2 & 154.6 & 162.3 & 204.4 & 246.1 & 363.7 & 318.3 & 294.4 \\
\hline Social Security contributions & 1328.2 & 1445.2 & 1546.9 & 1780.8 & 1837.3 & 1925.1 & 2204.9 & 2446.2 & 2823.9 & 3431.5 & 3865.8 \\
\hline
\end{tabular}

Note: "Social Security contributions" are not included in total "Taxes". Not all sub-items of "Taxes on goods and services" are listed.

Source: Government of Tunisia. 
Alm, WP 34, May 2015

Table 2. Composition of Consolidated Central Government Revenues for Tunisia (as percent of total taxes)

\begin{tabular}{|c|c|c|c|c|c|c|c|c|c|c|c|}
\hline & 2000 & 2001 & 2002 & 2003 & 2004 & 2005 & 2006 & 2007 & 2008 & 2009 & 2010 \\
\hline Taxes & 100 & 100 & 100 & 100 & 100 & 100 & 100 & 100 & 100 & 100 & 100 \\
\hline Taxes on income, profits, and capital gains & 28.12 & 29.38 & 31.49 & 32.83 & 32.89 & 36.51 & 36.68 & 38.89 & 40.25 & 39.49 & 39.62 \\
\hline Personal Income Tax & 17.99 & 18.53 & 18.88 & 19.74 & 19.81 & 19.28 & 20.27 & 20.50 & 18.93 & 20.22 & 20.52 \\
\hline Corporate Income Tax & 10.13 & 10.85 & 12.61 & 13.09 & 13.08 & 17.23 & 16.41 & 18.39 & 21.32 & 19.27 & 19.10 \\
\hline Taxes on payroll and workforce & 1.88 & 1.73 & 1.26 & 1.79 & 1.67 & 1.44 & 1.62 & 1.56 & 1.26 & 1.45 & 1.56 \\
\hline Taxes on property & 2.14 & 2.15 & 2.16 & 2.05 & 2.05 & 2.15 & 2.44 & 2.28 & 2.10 & 2.25 & 2.20 \\
\hline Taxes on goods and services & 51.13 & 50.74 & 50.38 & 50.67 & 50.88 & 48.54 & 47.90 & 45.99 & 44.67 & 45.71 & 45.34 \\
\hline VAT & 33.98 & 33.55 & 32.71 & 32.74 & 33.46 & 31.41 & 31.32 & 30.13 & 30.72 & 30.92 & 31.65 \\
\hline Excises & 13.92 & 13.91 & 14.22 & 14.39 & 14.07 & 13.29 & 12.69 & 12.09 & 10.61 & 10.72 & 10.20 \\
\hline Taxes on international. trade and transactions & 14.68 & 14.07 & 12.30 & 10.95 & 10.37 & 9.30 & 8.95 & 8.68 & 8.52 & 8.40 & 8.97 \\
\hline Other taxes & 2.05 & 1.92 & 2.41 & 1.72 & 2.13 & 2.05 & 2.41 & 2.59 & 3.21 & 2.71 & 2.31 \\
\hline
\end{tabular}

Note: "Social Security contributions" are not included in total "Taxes". Not all sub-items of "Taxes on goods and services" are listed.

Source: Government of Tunisia. 
Alm, WP 34, May 2015

Table 3. Composition of Consolidated Central Government Revenues for Tunisia (as percent of GDP)

\begin{tabular}{|c|c|c|c|c|c|c|c|c|c|c|c|}
\hline & 2000 & 2001 & 2002 & 2003 & 2004 & 2005 & 2006 & 2007 & 2008 & 2009 & 2010 \\
\hline Taxes & $\begin{array}{l}19.29 \\
\end{array}$ & 19.60 & 19.54 & 18.75 & 18.67 & 18.88 & 18.51 & 19.06 & 20.49 & 20.02 & 20.12 \\
\hline Taxes on income, profits, and capital gains & 5.43 & 5.76 & 6.15 & 6.15 & 6.14 & 6.89 & 6.79 & 7.41 & 8.25 & 7.90 & 7.97 \\
\hline Personal Income Tax & 3.47 & 3.63 & 3.69 & 3.70 & 3.70 & 3.64 & 3.75 & 3.91 & 3.88 & 4.05 & 4.13 \\
\hline Corporate Income Tax & 1.95 & 2.13 & 2.46 & 2.45 & 2.44 & 3.25 & 3.04 & 3.51 & 4.37 & 3.86 & 3.84 \\
\hline Taxes on payroll and workforce & 0.36 & 0.34 & 0.25 & 0.33 & 0.31 & 0.27 & 0.30 & 0.30 & 0.26 & 0.29 & 0.31 \\
\hline Taxes on property & 0.41 & 0.42 & 0.42 & 0.38 & 0.38 & 0.41 & 0.45 & 0.43 & 0.43 & 0.45 & 0.44 \\
\hline Taxes on goods and services & 9.86 & 9.94 & 9.85 & 9.50 & 9.50 & 9.16 & 8.87 & 8.77 & 9.15 & 9.15 & 9.12 \\
\hline VAT & 6.56 & 6.57 & 6.39 & 6.14 & 6.25 & 5.93 & 5.80 & 5.74 & 6.29 & 6.19 & 6.37 \\
\hline Excises & 2.69 & 2.73 & 2.78 & 2.70 & 2.63 & 2.51 & 2.35 & 2.31 & 2.17 & 2.15 & 2.05 \\
\hline Taxes on international. trade and transactions & 2.83 & 2.76 & 2.40 & 2.05 & 1.94 & 1.76 & 1.66 & 1.66 & 1.75 & 1.68 & 1.80 \\
\hline Other taxes & 0.40 & 0.38 & 0.47 & 0.32 & 0.40 & 0.39 & 0.45 & 0.49 & 0.66 & 0.54 & 0.46 \\
\hline Social Security contributions & 4.51 & 4.55 & 4.70 & 5.03 & 4.73 & 4.60 & 4.82 & 4.90 & 5.11 & 5.84 & 6.10 \\
\hline
\end{tabular}

Note: "Social Security contributions" are not included in total "Taxes". Not all sub-items of "Taxes on goods and services" are listed in the table.

Source: Government of Tunisia and World Development Indicators. 
Alm, WP 34, May 2015

Table 4. Tax Revenues (revenues as percent of GDP)

\begin{tabular}{|l|c|c|c|c|}
\hline \multirow{2}{*}{ Country Group } & \multicolumn{4}{|c|}{ Decade } \\
\cline { 2 - 5 } & $\mathbf{1 9 7 0}$ & $\mathbf{1 9 8 0}$ & $\mathbf{1 9 9 0 s}$ & $\mathbf{2 0 0 0}$ \\
\hline Industrialized & 30.1 & 33.7 & 35.5 & 33.4 \\
& $(8.3)$ & $(8.4)$ & $(8.5)$ & $(8.4)$ \\
\hline Developing & 16.2 & 17.3 & 17.0 & 17.0 \\
& $(7.6)$ & $(8.3)$ & $(7.7)$ & $(7.9)$ \\
\hline Transition & & 47.7 & 29.6 & 29.1 \\
& & $(9.7)$ & $(11.0)$ & $(9.0)$ \\
\hline Total & 19.8 & 21.6 & 22.6 & 21.8 \\
& $(9.9)$ & $(11.3)$ & $(11.5)$ & $(10.4)$ \\
\hline
\end{tabular}

Notes: The numbers represent decade averages for the relevant country groupings, with standard deviations in parentheses.

Source: International Monetary Fund Government Finance Statistics, various issues.

Table 5. Tax Structure (taxes as percent of total taxes)

\begin{tabular}{|l|l|l|l|l|}
\hline & \multicolumn{5}{|c|}{ Decade } \\
\hline Income Tax & \multicolumn{1}{|c|}{$\mathbf{1 9 7 0 s}$} & $\mathbf{1 9 8 0}$ & \multicolumn{1}{c|}{$\mathbf{1 9 9 0 s}$} & $\mathbf{2 0 0 0}$ \\
\hline Industrialized & 35.5 & 37.8 & 38.6 & 53.8 \\
& $(15.1)$ & $(13.7)$ & $(10.9)$ & $(8.1)$ \\
\hline Developing & 29.6 & 28.6 & 27.6 & 28.3 \\
& $(19.5)$ & $(19.1)$ & $(16.5)$ & $(17.8)$ \\
\hline Transition & 12.3 & 16.5 & 26.7 & 23.3 \\
& $(14.4)$ & $(13.8)$ & $(9.6)$ & $(6.5)$ \\
\hline Total & 30.7 & 30.2 & 29.7 & 28.5 \\
& $(18.8)$ & $(18.5)$ & $(15.4)$ & $(16.4)$ \\
\hline Indirect Taxes & \multicolumn{5}{|l}{} \\
\hline Industrialized & 27.2 & 29.4 & 30.5 & 19.8 \\
& $(10.1)$ & $(9.0)$ & $(10.1)$ & $(10.7)$ \\
\hline Developing & 25.2 & 29.3 & 34.9 & 40.1 \\
& $(14.3)$ & $(17.3)$ & $(17.7)$ & $(17.8)$ \\
\hline Transition & 10.5 & 21.8 & 37.9 & 42.1 \\
& $(11.1)$ & $(14.4)$ & $(12.3)$ & $(9.6)$ \\
\hline Total & 25.3 & 28.9 & 34.2 & 39.0 \\
& $(13.5)$ & $(15.8)$ & $(15.9)$ & $(16.4)$ \\
\hline Taxes on International Trade & \multicolumn{3}{|l}{} \\
\hline Industrialized & 4.6 & 2.8 & 1.0 & 1.0 \\
& $(5.8)$ & $(4.3)$ & $(2.0)$ & $(0.6)$ \\
\hline Developing & 32.4 & 30.7 & 25.6 & 19.0 \\
& $(18.4)$ & $(20.2)$ & $(18.9)$ & $(18.0)$ \\
\hline Transition & 7.7 & 5.2 & 7.6 & 5.4 \\
& $(8.2)$ & $(3.8)$ & $(7.3)$ & $(5.5)$ \\
\hline Total & 25.2 & 23.8 & 18.2 & 14.1 \\
& $(20.2)$ & $(21.4)$ & $(18.9)$ & $(16.5)$ \\
\hline
\end{tabular}

Notes: The numbers represent decade averages for the relevant country groupings, with standard deviations in parentheses.

Source: International Monetary Fund Government Finance Statistics, various issues. 
Alm, WP 34, May 2015

Table 6. Tunisia's Tax Structure in International Perspective (individual tax as percent of total taxes)

\begin{tabular}{|c|c|c|c|c|c|}
\hline Country & $\begin{array}{c}\text { Income and } \\
\text { Payroll } \\
\text { Taxes }\end{array}$ & $\begin{array}{c}\text { Property } \\
\text { Taxes }\end{array}$ & $\begin{array}{c}\text { Indirect } \\
\text { Taxes }\end{array}$ & $\begin{array}{c}\text { Taxes on } \\
\text { International } \\
\text { Trade }\end{array}$ & $\begin{array}{l}\text { Other } \\
\text { Taxes }\end{array}$ \\
\hline Argentina & 26.3 & 8.4 & 35.0 & 3.8 & 0.1 \\
\hline Bahrain & 36.3 & 3.8 & 16.1 & 43.8 & 0.0 \\
\hline Belarus & 27.1 & 3.2 & 62.3 & 4.9 & 0.0 \\
\hline Bhutan & 53.4 & 0.4 & 42.6 & 3.6 & 0.0 \\
\hline Bolivia & 10.9 & 10.5 & 65.1 & 6.2 & 0.1 \\
\hline Bulgaria & 31.6 & 1.5 & 61.2 & 3.8 & 1.8 \\
\hline Canada & 57.0 & 11.7 & 27.3 & 0.8 & 0.0 \\
\hline Chile & 22.8 & 4.1 & 61.3 & 7.6 & 4.2 \\
\hline Congo, Dem. Republic & 12.6 & 0.0 & 23.8 & 24.7 & $38.8^{a}$ \\
\hline Congo, Republic & 11.3 & 0.0 & 64.5 & 22.9 & 1.4 \\
\hline Costa Rica & 22.4 & 0.5 & 68.7 & 8.4 & 0.0 \\
\hline Cote d'Ivoire & 29.1 & 1.7 & 23.3 & 45.4 & 0.5 \\
\hline Croatia & 22.1 & 1.8 & 66.4 & 8.7 & 1.0 \\
\hline Czech Republic & 40.1 & 2.4 & 53.9 & 3.1 & 0.4 \\
\hline Denmark ${ }^{1}$ & 60.8 & 3.6 & 34.6 & 0.0 & 1.0 \\
\hline Dominican Republic & 20.5 & 1.1 & 28.5 & 48.5 & 1.4 \\
\hline Estonia & 39.2 & 2.2 & 58.4 & 0.2 & 0.0 \\
\hline Georgia & 25.9 & 9.4 & 54.6 & 6.1 & 0.0 \\
\hline Hungary & 36.1 & 2.6 & 55.6 & 4.0 & 1.7 \\
\hline India & 37.3 & 0.1 & 37.3 & 25.1 & 0.2 \\
\hline Iran & 53.0 & 2.5 & 19.9 & 23.3 & 1.3 \\
\hline Israel & 53.2 & 7.7 & 37.3 & 0.9 & 0.7 \\
\hline Jamaica & 41.9 & 0.6 & 40.5 & 8.9 & 8.1 \\
\hline Kazakhstan & 52.7 & 6.0 & 36.3 & 4.1 & 0.7 \\
\hline Latvia & 36.9 & 4.9 & 56.6 & 1.6 & 0.0 \\
\hline Lithuania & 40.5 & 2.7 & 55.3 & 1.5 & 0.0 \\
\hline Macao, China & 8.9 & 6.5 & 82.1 & 0.0 & 2.5 \\
\hline Madagascar & 15.7 & 1.0 & 29.1 & 53.5 & 0.6 \\
\hline Maldives & 4.6 & 0.0 & 29.7 & 64.4 & 1.3 \\
\hline Mauritius & 14.6 & 5.8 & 46.2 & 33.4 & 0.1 \\
\hline Mexico & 32.6 & 1.7 & 59.6 & 3.9 & 0.7 \\
\hline Moldova & 17.5 & 6.1 & 68.9 & 7.5 & 0.1 \\
\hline Mongolia & 28.4 & 0.1 & 56.2 & 10.1 & 1.3 \\
\hline Myanmar & 34.5 & 0.0 & 58.2 & 7.2 & 0.0 \\
\hline Nepal & 22.4 & 3.4 & 41.6 & 32.6 & 0.0 \\
\hline Nicaragua & 17.1 & -0.2 & 73.6 & 9.4 & 0.0 \\
\hline Pakistan & 28.1 & 1.2 & 44.7 & 16.0 & $10.1^{b}$ \\
\hline Paraguay & 17.9 & 0.0 & 59.4 & 18.2 & 4.4 \\
\hline Peru & 26.8 & 0.0 & 67.0 & 12.4 & 3.2 \\
\hline Poland & 35.5 & 5.2 & 55.9 & 3.5 & 0.0 \\
\hline Puerto Rico & 66.8 & 0 & 22.0 & 0 & 11.2 \\
\hline Romania & 34.5 & 2.7 & 54.8 & 6.2 & 1.1 \\
\hline Russian Federation & 33.2 & 4.5 & 44.4 & 13.0 & 0.1 \\
\hline Seychelles & 26.7 & 0.1 & 7.8 & 63.1 & 2.3 \\
\hline Singapore & 50.2 & 6.5 & 31.2 & 2.5 & 9.6 \\
\hline Slovak Republic & 35.9 & 2.8 & 54.3 & 7.0 & 0.0 \\
\hline Slovenia & 36.3 & 2.5 & 57.6 & 3.6 & 0.0 \\
\hline South Africa & 54.0 & 5.8 & 34.8 & 3.1 & 0.7 \\
\hline Switzerland & 58.1 & 12.3 & 28.6 & 1.1 & 0.0 \\
\hline Tajikistan & 16.0 & 5.6 & 63.8 & 12.6 & 0.0 \\
\hline Thailand & 32.2 & 2.3 & 53.1 & 11.9 & 0.5 \\
\hline Tunisia & 36.5 & 2.1 & 48.5 & 9.3 & 2.0 \\
\hline
\end{tabular}


Alm, WP 34, May 2015

\begin{tabular}{|lccccc|} 
Turkey & 37.4 & 4.0 & 52.1 & 1.7 & 4.7 \\
Ukraine & 42.3 & 0.0 & 52.4 & 5.3 & 0.0 \\
United States & 66.4 & 13.2 & 19.5 & 1.0 & 0.0 \\
Uruguay & 26.2 & 9.3 & 57.1 & 4.7 & 3.1 \\
Venezuela & 42.5 & 5.5 & 39.7 & 11.4 & 0.9 \\
\hline Mean (unweighted) & $\mathbf{3 2 . 6}$ & $\mathbf{3 . 6}$ & $\mathbf{4 7 . 5}$ & $\mathbf{1 3 . 4}$ & $\mathbf{2 . 0}$ \\
\hline
\end{tabular}

Source: International Monetary Fund Government Finance Statistics, various issues.

Table 7. Statutory Corporate and Statutory VAT Tax Rates, Selected Countries

\begin{tabular}{|l|c|c|}
\hline Country & Corporate Income Tax (percent) & VAT (percent) \\
\hline Turkey & 20.0 & 18.0 \\
Malaysia & $20.0,28.0$ & 10.0 \\
Thailand & 30.0 & 7.0 \\
Korea & $14.3,27.5$ & 10.0 \\
Indonesia & 10 to 30 & 10.0 \\
Australia & 30.0 & 10.0 \\
India & 33.7 & 12.5 \\
Pakistan & 35.0 & 15.0 \\
Egypt & 20.0 & 10.0 \\
China & 33.0 & 17.0 \\
Sri Lanka & 35.0 & 15.0 \\
Bangladesh & 40.0 & 15.0 \\
Tunisia & 30 & 18.0 \\
\hline
\end{tabular}

Source: Doing Business 2010. 
Table 8. Tax Rates from Payroll Taxes and Social Security Contributions in OECD Countries and Tunisia (in percent)

\begin{tabular}{|c|c|c|c|c|c|}
\hline Country & $\begin{array}{l}\text { Total Tax Rate } \\
(\mathrm{A})=(\mathrm{B})+(\mathrm{C})\end{array}$ & $\begin{array}{l}\text { Payroll Tax Rate } \\
\text { (Other than SSC) } \\
\text { (B) }\end{array}$ & $\begin{array}{c}\text { Total Social Security } \\
\text { Contribution (SSC) } \\
\text { Rates } \\
(\mathrm{C})=(\mathrm{D})+(\mathrm{E}) \\
\end{array}$ & $\begin{array}{c}\text { Social Security } \\
\text { Charges } \\
\text { to Employers } \\
\text { (D) }\end{array}$ & $\begin{array}{c}\text { Social Security } \\
\text { Charges } \\
\text { to Employees } \\
\text { (E) } \\
\end{array}$ \\
\hline Australia & Up to 7 & Up to 7 & 0 & 0 & 0 \\
\hline Austria & $29.15-29.3$ & 7.5 & $21.65-21.8$ & $21.65-21.8$ & NA \\
\hline Belgium & $32.89-48.66$ & 0 & $32.89-48.66$ & $32.89-48.66$ & NA \\
\hline Canada & Rate varies & $1-4.5$ & Rate Varies & Rate Varies & NA \\
\hline Denmark & 0 & 0 & 0 & 0 & 0 \\
\hline Finland & $26.4-28.4$ & 0 & $26.4-28.4$ & $20.1-22.1$ & 6.3 \\
\hline France & $42.25-64.63$ & $4.25-13.60$ & $38-51.03$ & $38-51.03$ & NA \\
\hline Germany & 40.8 & 0 & 40.8 & 20.4 & 20.4 \\
\hline Greece & $43.86-54.36$ & 0 & $43.86-54.36$ & $27.96-34.96$ & $15.90-19.40$ \\
\hline Ireland & 18 & 0 & 18 & 12 & 6 \\
\hline Italy & $36-42$ & 0 & $36-42$ & $32 \%-36$ & $4-6$ \\
\hline Mexico & $42.92-44.92$ & $6-8$ & 36.92 & 30.19 & 6.73 \\
\hline Netherlands & 25.31 & 0 & 25.31 & 18.66 & 6.65 \\
\hline Norway & 26.6 & 0 & 26.6 & 26.6 & NA \\
\hline Portugal & 23.75 & 0 & 23.75 & 23.75 & 0 \\
\hline Spain & $37.15-37.2$ & 0 & $37.15-37.2$ & 30.8 & $6.35-6.4$ \\
\hline Sweden & 81.34 & 48.52 & 32.82 & 32.82 & 0 \\
\hline Switzerland & 13.1 & 0 & 13.1 & 6.55 & 6.55 \\
\hline Turkey & $55.5-61$ & 0 & $55.5-61$ & $32.5-38$ & 23 \\
\hline United Kingdom & $0-23.6$ & 0 & $0-23.6$ & $0-11.8$ & $0-11.8$ \\
\hline United States & 15.3 & 0 & 15.3 & 7.65 & 7.65 \\
\hline Tunisia & $26.15-38.75$ & Up to 9 & $26.15-29.75$ & $16.97-20.57$ & 9.18 \\
\hline
\end{tabular}

Notes: All contributions are computed as a percentage of the employee's salary.

Source: International Bureau of Fiscal Documentation (IBFD), various issues. 
Alm, WP 34, May 2015

Table 9: Tax Wedge in OECD Countries, 2011

\begin{tabular}{|l|c|}
\hline Country & Tax Wedge (percent of labor costs) \\
\hline Belgium & 55.5 \\
\hline Germany & 49.8 \\
\hline Hungary & 49.4 \\
\hline France & 49.4 \\
\hline Austria & 48.4 \\
\hline Italy & 47.6 \\
\hline Sweden & 42.8 \\
\hline Finland & 42.7 \\
\hline Slovenia & 42.6 \\
\hline Czech Republic & 42.5 \\
\hline Estonia & 40.1 \\
\hline Spain & 39.9 \\
\hline Portugal & 39.0 \\
\hline Slovak Republic & 38.9 \\
\hline Denmark & 38.4 \\
\hline The Netherlands & 37.8 \\
\hline Turkey & 37.7 \\
\hline Norway & 37.5 \\
\hline Luxembourg & 36.0 \\
\hline Poland & 34.3 \\
\hline Iceland & 34.0 \\
\hline United Kingdom & 32.5 \\
\hline Canada & 30.8 \\
\hline Japan & 30.8 \\
\hline United States & 29.5 \\
\hline Ireland & 26.8 \\
\hline Australia & 26.7 \\
\hline Switzerland & 21.0 \\
\hline Korea & 20.3 \\
\hline Israel & 19.8 \\
\hline Mexico & 16.2 \\
\hline New Zealand & 15.9 \\
\hline Chile & 7.0 \\
\hline & \\
\hline & \\
\hline
\end{tabular}

Source: OECD (2012).

Table 10. Shadow Economy Estimates by Income Group, 1984-2006 (as percent of GDP)

\begin{tabular}{|l|c|c|c|c|c|}
\hline Income Group & Observations & Mean & Standard Deviation & Minimum & Maximum \\
\hline Low Income & 621 & 38.2 & 10.3 & 20.5 & 85.8 \\
\hline Lower Middle Income & 572 & 37.2 & 10.3 & 17.5 & 84.5 \\
\hline Upper Middle Income & 395 & 33.4 & 7.2 & 21.3 & 68.2 \\
\hline High Income, Non-OECD & 118 & 24.3 & 7.1 & 14.1 & 44.1 \\
\hline OECD & 475 & 16.9 & 3.6 & 10.4 & 30.3 \\
\hline All Countries (Unweighted) & 2181 & 31.7 & 12.0 & 10.4 & 85.8 \\
\hline
\end{tabular}

Source: Alm and Embaye (2013) 